\title{
Tenascin and Extracellular Matrix Glycoproteins: From Promotion to Polarization of Neurite Growth in vitro
}

\author{
André Lochter and Melitta Schachner \\ Department of Neurobiology, Swiss Federal Institute of Technology, Hönggerberg, 8093 Zürich, Switzerland
}

The extracellular matrix molecules tenascin, laminin, and fibronectin, the cell adhesion molecule L1, and the lectin concanavalin A (ConA) were tested for their effects on neuritogenesis in cultures of hippocampal neurons. We analyzed neurite outgrowth between 3 and $21 \mathrm{hr}$ after plating and found that, on polyornithine as control substrate, lengths of axon-like major neurites and dendrite-like minor neurites increased continuously with time in culture. Moreover, growth of minor neurites was faster than growth of major neurites. When the extracellular matrix molecules tenascin, laminin, and fibronectin were coated on polyornithine substrates, growth of all neurites was faster than on control substrates during the first hours of culture. After this initial phase of enhanced neurite outgrowth, elongation of major neurites continued at a higher rate than on the control substrate and growth of minor neurites ceased after $12 \mathrm{hr}$. Correspondingly, neuronal polarity was strongly increased on the extracellular matrix substrates during later phases of culture. In contrast, lengths of both major and minor neurites were increased over control values on $L 1$ and ConA substrates at all time points investigated. Thus, neuronal polarity was similar for control, L1, and ConA substrates. Spreading of neuronal cell bodies was reduced by about $50 \%$ on tenascin, laminin, and fibronectin and by less than $20 \%$ on L1 and ConA substrates after $21 \mathrm{hr}$ of culture, when compared to the control substrate. Neuron-to-substrate adhesion was reduced on all three extracellular matrix substrates but not affected on L1 or ConA substrates, after 3 and 21 hr of culture. These observations indicate that induction of neuronal polarity is not a general feature of neurite outgrowthpromoting molecules, such as $\mathrm{L} 1$ or $\operatorname{Con} A$, but a distinctive property of the three extracellular matrix glycoproteins studied, and may suggest that enhancement of polarity is correlated with decreased strength of adhesion.

[Key words: neurite outgrowth, polarity, axon, tenascin, laminin, fibronectin, $L 1$, cell adhesion molecules, concanavalin A, hippocampus]

Neuronal differentiation is accompanied by neurite growth and compartmentalization into axons and dendrites. This process is fundamental for the function of the nervous system since it

Received Nov. 2, 1992; revised Mar. 22, 1993; accepted Apr. 13, 1993.

We thank Jürgen Holm for writing the program for morphometric quantifications on the IBAS image analysis system, Dr. Joanne Taylor for helpful discussions and comments on the manuscript, and Dr. Andrew Matus for monoclonal antibodies against tau. A.L. was supported by a predoctoral fellowship of the Studienstiftung des Deutschen Volkes.

Correspondence should be addressed to André Lochter at the above address. Copyright (c) 1993 Society for Neuroscience $0270-6474 / 93 / 133986-15 \$ 05.00 / 0$ is specialized for transmitting signals in a polarized manner. Hippocampal neurons have proven useful for the study of neuronal polarization in vitro. When maintained at low cell density on the adhesive substrate polylysine in the presence of astrocyte-conditioned medium, they pass through a sequence of developmental stages to become fully differentiated neurons of polarized appearance with one long axon and several short dendrites (Dotti et al., 1988). After plating, hippocampal neurons attach to the culture substrate and spread, forming veil-like lamellipodia (stage 1). At stage 2, neurites extend out of these lamellipodia. Later, one neurite of these minor neurites starts to elongate faster than the others, forming a long, major neurite that later differentiates into an axon (stages 3-5). From stage 3 onward, proteins that are homogeneously distributed over all cellular compartments at earlier stages become selectively enriched in major or minor neurites. Synapsin I, synaptophysin, and growth-associated protein 43 (GAP-43) become concentrated in major neurites (Goslin et al., 1988, 1990; Fletcher et al., 1991), whereas microtubule-associated protein 2 (MAP2) becomes restricted to minor neurites (Caceres et al., 1984, 1986). Furthermore, the glycosylphosphatidylinositol-anchored glycoprotein Thy-1 is enriched in axons of stage 5 neurons (Dotti et al., 1991). Ultrastructurally, hippocampal axons in vitro, as in vivo, lack polyribosomes that are prominent in dendrites (Davis et al., 1987). Axons contain filamentous cytoskeletal elements that are packed more densely than in dendrites, with axoplasmic organelles being largely restricted to axonal branch points (Bartlett and Banker, 1984). The orientation of microtubules also differs between axons and dendrites (Baas et al., 1988, 1989). In axons, all microtubules are oriented with their plus ends toward the axonal tip, whereas in dendrites both microtubules with minus and plus ends oriented toward the neurite tip are present.

Despite this knowledge, relatively little is known about the factors that influence neuronal polarity. Experiments with neuron-astrocyte cocultures have demonstrated the influence of the cellular environment on polarity and implicated cell surface and extracellular matrix molecules in this process (Denis-Donini et al., 1984; Chamak et al., 1987; Rousselet et al., 1988, 1990; Tropea et al., 1988; Johnson et al., 1989; Qian et al., 1992). When neurons are cultured together with astrocytes originating from a different brain region (heterotopic coculture), axonal growth is favored compared to a situation where neurons are cocultured with astrocytes from the same origin as the neurons (homotopic coculture). On the other hand, dendritic growth is, at least for some neuronal cell types, favored in a homotopic situation.

Several reports have stressed the importance of extracellular matrix molecules for the establishment of neuronal polarity 
(Chamak and Prochiantz, 1989; Lcin and Higgins, 1989; Lcin et al., 1991, 1992; Lafont et al., 1992; Osterhout et al., 1992). The extracellular matrix components the mostly studied in the developing nervous system are the multimeric glycoproteins laminin and fibronectin, which are expressed at stages critical for neuronal differentiation in situ (e.g., Hatten et al., 1982; Steward and Pearlman, 1987; Chun and Shatz, 1988; Liesi and Silver, 1988; McLoon et al., 1988; Gordon-Weeks et al., 1989; Hagg et al., 1989) and are functional in neurite outgrowth in vitro (e.g., Akers et al., 1981; Manthorpe et al., 1983; Rogers et., 1983; Buettner and Pittman, 1991).

Tenascin is expressed during restricted time periods closely correlated with the differentiation of functional units of the CNS, such as the somatosensory cortical barrel field (Crossin et al., 1989; Steindler et al., 1989a,b; Jhaveri et al., 1991). Moreover, tenascin is involved in migration of cerebellar granule and neural crest cells (Chuong et al., 1987; Halfter et al., 1989; Husmann et al., 1992). It is reexpressed after injury of peripheral nerves (Daniloff et al., 1989; Martini et al., 1990) and, although less consistently, after trauma in the CNS (McKeon et al., 1991; U. Bartsch et al., 1992; Laywell et al., 1992). We and others have found that tenascin, offered as a substrate for central and peripheral neurons, promoted growth of all neurites (Wehrle and Chiquet, 1990; Lochter et al., 1991). Growth of neurites on polyornithine, laminin, fibronectin, or tenascin was, however, inhibited by tenascin when it was added in soluble form to the culture medium (Lochter et al., 1991). We concluded from these results that in vivo tenascin might have different effects on neurite growth depending on its association with molecules at the cell surface or in the extracellular matrix. The development of functional connections in the nervous system involves not only axon growth and guidance, but also sprouting of dendritic arbors in the axonal target area. It is therefore plausiblc to implicatc recognition molecules in both tasks: guidance of axons to and within their target regions and inhibition of maturation of dendrites beyond functional topographic units (Rakic, 1988; Steindler et al., 1989a).

We thus focused on investigating the influence of tenascin on neuronal polarity. We now present evidence that tenascin not only enhances neurite outgrowth at early stages of differentiation, but increases neuronal polarity at later phases. These effects were also observed for substrate-coated laminin and fibronectin, whereas the neural cell adhesion molecule L 1 and concanavalin A (ConA) promoted outgrowth of all neurites at all stages studied without enhancing polarity.

\section{Materials and Methods}

Glycoproteins. Laminin from Engelbreth-Holm-Swarm sarcoma cells and fibronectin from human serum were purchased from Boehringer Mannheim. Tenascin was immunoaffinity purified from 1-15-d-old mouse brains using monoclonal antibody columns (Faissner and Kruse, 1990). LI was immunoaffinity purified from detergent extracts of crude membrane fractions from adult mouse brains using monoclonal antibody columns (Rathjen and Schachner, 1984). Concanavalin A was purchased from Fluka.

Preparation of substrates. Hippocampal neurons were cultured either in multiwell tissue culture plates or on glass coverslips. Ninety-six well multiwell plates (Nunc) were pretreated for $1-2 \mathrm{hr}$ at $37^{\circ} \mathrm{C}$ with $1.5 \mu \mathrm{g} /$ $\mathrm{ml}$ poly-DL-ornithine (MW > 50,000; Sigma) in water, washed twice with water, and air dried. Glycoproteins were then coated in a volume of $35 \mu \mathrm{l}$ per well overnight at $37^{\circ} \mathrm{C}$ in phosphate-buffered saline, $\mathrm{pH} 7.4$ (PBS) or $\mathrm{Ca}^{2+} / \mathrm{Mg}^{2+}$-free Hank's balanced salt solution (CMF-HBSS). Tenascin, laminin, and fibronectin were used at a concentration of 25 $\mu \mathrm{g} / \mathrm{ml}$ and $\mathrm{L} 1$ and concanavalin A at $50 \mu \mathrm{g} / \mathrm{ml}$. These concentrations yielded maximal effects on neuronal differentiation, as specified in Results. For control, poly-DL-ornithine-coated wells were incubated overnight in PBS or CMF-HBSS. Before seeding the cells, wells were washed three times with PBS or CMF-HBSS.

Glass coverslips, $11 \mathrm{~mm}$ in diameter, were washed extensively with water and stored in ethanol until use. For substrate coating, coverslips were incubated with $1.5 \mu \mathrm{g} / \mathrm{ml}$ poly-DL-ornithine in water for $2-4 \mathrm{hr}$ at $37^{\circ} \mathrm{C}$, and then washed five times with water, air dried, and incubated overnight at $37^{\circ} \mathrm{C}$ with $40 \mu \mathrm{l}$ of $25 \mu \mathrm{g} / \mathrm{ml}$ tenascin in PBS, or PBS only (control). Before seeding the cells, coverslips were washed five times with PBS

Cell culture. Hippocampal neurons were prepared from brains of $18-$ 19-d-old SIV rat embryos. The day a vaginal plug was found was designated embryonic day 0 . The preparation was carried out as described previously (Lochter et al., 1991), with minor modifications. Dissected hippocampi were incubated for $15 \mathrm{~min}$ at room temperature in $0.25 \%$ (w/v) trypsin (Worthington) and $0.07 \%(w / v)$ DNase I (Worthington) in CMF-HBSS, washed three times with CMF-HBSS, and dissociated with a fire-polished Pasteur pipette in CMF-HBSS containing 0.05\% $(w / v)$ DNase I. The resulting cell suspension was pelleted by centrifugation at $150 \times g$ for $5 \mathrm{~min}$ and resuspended in chemically defined medium (following Rousselet et al., 1988) consisting of Dulbecco's modified Eagle's medium/F12 (1:1; Bethesda Research Laboratories), 2.4 $\mathrm{mg} / \mathrm{ml} \mathrm{NaHCO}, 33 \mathrm{~mm}$ D-glucose, $2 \mathrm{~mm}$ L-glutamine, $25 \mu \mathrm{g} / \mathrm{ml}$ insulin (Sigma), $100 \mu \mathrm{g} / \mathrm{ml}$ transferrin (Sigma), $20 \mathrm{~nm}$ progesterone (Sigma), 30 nM selenium, $6 \mathrm{~mm}$ putrescin, $1 \mathrm{~mm}$ pyruvate, $0.1 \%(\mathrm{w} / \mathrm{v})$ ovalbumin (grade $\mathrm{V}$, Sigma), $5 \mathrm{mM}$ HEPES, $\mathrm{pH} 7.2,5 \mathrm{IU} / \mathrm{ml}$ penicillin, and $5 \mu \mathrm{g} /$ $\mathrm{ml}$ streptomycin. Cells were plated at a density of 3000 cells per well or 6000 cells per coverslip (corresponding to 10,000 cells per $\mathrm{cm}^{2}$ ) in $50 \mu \mathrm{l}$ or $100 \mu \mathrm{l}$ of chemically defined medium, respectively.

Plating efficiencies and survival of cells on the different substrates in multiwell plates were determined in two experiments by counting the total number of cells attached to the culture substrate and determining the number of live cells by trypan blue exclusion in at least 20 visual fields per experiment (Table 1).

Histochemistry and immunocytochemistry. For morphometric anal-

Table 1. Plating efficiency and survival

\begin{tabular}{lllll} 
& \multicolumn{3}{l}{ Plating efficiency (\%) } & \multicolumn{2}{l}{ Survival (\%) } \\
\cline { 2 - 5 } Substrate & $3 \mathrm{hr}$ & $21 \mathrm{hr}$ & $3 \mathrm{hr}$ & $21 \mathrm{hr}$ \\
\hline Control & $60.8 \pm 11.65$ & $67.0 \pm 7.27$ & $90.7 \pm 9.31$ & $83.0 \pm 7.47$ \\
TN & $67.3 \pm 18.10$ & $70.8 \pm 16.93$ & $96.5 \pm 2.82$ & $87.5 \pm 6.92$ \\
LN & $63.6 \pm 14.00$ & $67.5 \pm 10.73$ & $93.4 \pm 3.78$ & $87.8 \pm 6.15$ \\
FN & $64.8 \pm 12.29$ & $70.5 \pm 14.15$ & $94.5 \pm 2.72$ & $83.8 \pm 9.59$ \\
L1 & $63.0 \pm 11.90$ & $63.3 \pm 12.60$ & $96.3 \pm 3.64$ & $84.2 \pm 5.44$ \\
ConA & $65.9 \pm 15.51$ & $68.4 \pm 12.50$ & $94.6 \pm 1.95$ & $79.6 \pm 2.23$
\end{tabular}

Data show plating efficiencies and survival of hippocampal neurons in multiwell plates. Cells were maintained on control, tenascin (TN), laminin (LN), fibronectin (FN), LI, and ConA substrates. Plating efficiencies and survival rates were determined 3 and $21 \mathrm{hr}$ after plating. The obtained results for the different culture conditions are given as percentage of input cells that had adhered to the substrate (plating efficiency) (mean \pm SD), or percentage of cells that excluded trypan blue (live cells) (mean \pm SD). Comparison of values with the Newman-Keuls test did not result in significant differences among culture substrates $(p<0.05)$. 


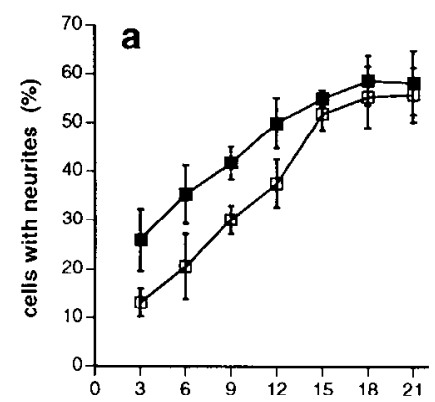

time In culture (hours)
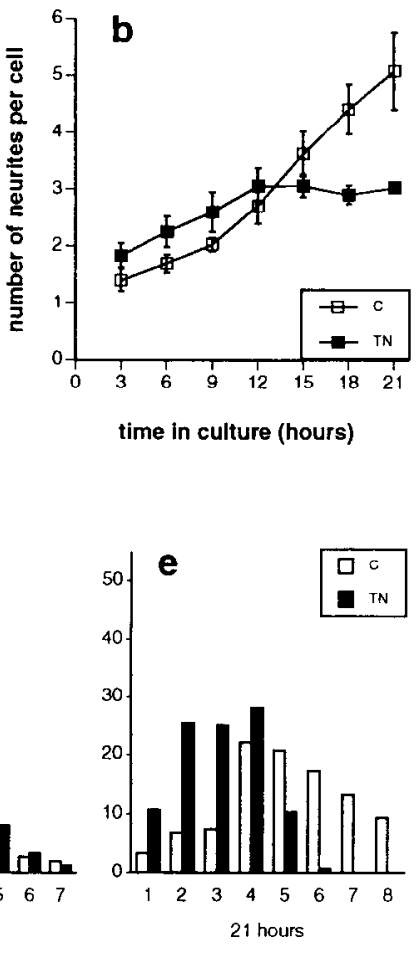

number of neurites per cell
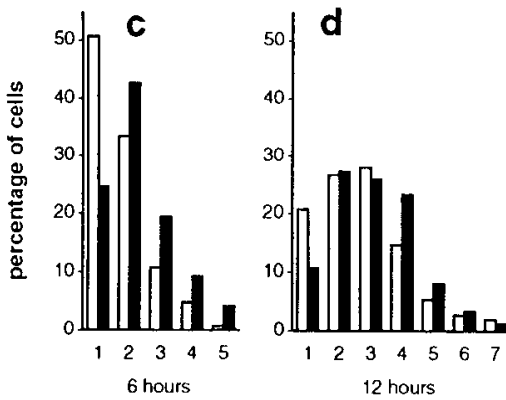

Figure 1. Time dependence of the effects of substrate-bound tenascin on the fraction of process-bearing cells and on the average number of neurites per cell. Cells were maintained for $3,6,9,12,15,18$, and 21 $\mathrm{hr}$ in culture and the proportion of cells with neurites $(a)$ and the number of neurites per cell $(b)$ were counted. Results are shown as means \pm SD for neurons on the control substrate ( $C$, open squares) and on tenascin (TN, solid squares). Distributions of the number of neurites per cell are shown for $6(c), 12(d)$, and $21(e)$ hr for neurons on the control substrate (open bars) and on tenascin (solid bars). Neuron populations in $c-e$ are the same as in $b$ for 6,12 , and $21 \mathrm{hr}$. For significance levels, see Table 2 .

ysis of cells in multiwell plates, neurons were fixed by gentle addition of $10 \mu \mathrm{l}$ of $25 \%$ glutaraldehyde in water to the culture medium and incubation for $30 \mathrm{~min}$ at room temperature or $1 \mathrm{hr}$ at $4^{\circ} \mathrm{C}$. Fixed cells were washed twice with water and stained for $10 \mathrm{~min}$ with $0.5 \%(\mathrm{w} / \mathrm{v})$ toluidine blue (Sigma) in $2.5 \%(\mathrm{w} / \mathrm{v})$ sodium carbonate at room temperature. Stained cells were washed six times with water and air dried.

For silver-enhanced immunostaining in multiwell plates, cells were fixed by adding $50 \mu \mathrm{l}$ of $8 \%$ formaldehyde in PBS to the cell culture medium. This and all other steps were carried out at room temperature. After $15 \mathrm{~min}$, the fixative was removed and $100 \mu \mathrm{l}$ of $4 \%$ formaldehyde in PBS was added. After a further $15 \mathrm{~min}$, wells were washed three times with PBS and incubated for $15 \mathrm{~min}$ with $200 \mu \mathrm{l}$ of $50 \mathrm{mM} \mathrm{NH}_{4} \mathrm{Cl}$. Wells were then blocked for $2 \mathrm{hr}$ with $200 \mu \mathrm{l}$ of $1 \%(\mathrm{w} / \mathrm{v})$ fatty acidfree BSA (Sigma) in PBS. The blocking buffer was removed and $50 \mu \mathrm{l}$ per well of polyclonal antibodies to the neural cell adhesion molecule N-CAM (Faissner et al., 1984; Gennarini et al., 1984) in $0.2 \%(w / v)$ BSA in PBS was added and incubated for $1 \mathrm{hr}$. After six washes with PBS, $50 \mu 1$ per well of gold-conjugated goat anti-rabbit antibodics (GPBIO ASSAY, Aurion) was added at a 1:20 dilution in 0.2\% BSA in PBS and incubated for $2 \mathrm{hr}$. After six washes with PBS, wells were incubated for 10 min with $2 \%$ glutaraldehyde in PBS and thereafter washed five times with water. Gold particles were visualized by incubation with R-GENT silver-enhancing system (Aurion) according to the manufacturer's instructions. The reaction was terminated by washing three times with water. Wells were then filled with $87 \%$ glycerol for photography.

For immunostaining of neurons on glass coverslips, cells were fixed by gentle removal of the medium with a Pasteur pipette and addition of 3\% freshly prepared formaldehyde and $0.2 \%$ glutaraldehyde in PBS. Cells were incubated for $20 \mathrm{~min}$ at room temperature, washed five times with PBS, and then permeabilized and blocked with $10 \%$ fetal calf serum and $0.2 \%(\mathrm{v} / \mathrm{v})$ Tween-20 in PBS (BP buffer). Monoclonal antibodies to the microtubule-associated axonal marker tau (Binder et al., 1985) were diluted in BP buffer and incubated overnight at $4^{\circ} \mathrm{C}$. After five washes with PBS and one wash with BP buffer, cells were reacted with rhodamine-labeled anti-mouse antibodies in BP buffer for $2 \mathrm{hr}$ at room temperature, and then washed five times with PBS and embedded in $90 \%$ glycerol (v/v), $10 \%$ PBS containing $2 \%(\mathrm{w} / \mathrm{v}) \mathrm{NaI}$.

Adhesion assay. For the adhesion assay cells were cultured in multiwell plates for 3 and $21 \mathrm{hr}$ as described above. Culture plates were then agitated on a rotary shaker at room temperature for $4 \mathrm{~min}$ at $400 \mathrm{rpm}$ and 1 additional minute at $500 \mathrm{rpm}$. Cells were fixed by addition of glutaraldehyde and stained with toluidine blue as described above. The number of attached cells was counted in 10 visual fields (about $0.6 \mathrm{~mm}^{2}$ per visual field) in three experiments.

Morphometry and statistical evaluation. For morphometric analysis, only cells without contact with other cells were evaluated. Neurites were defined as those processes with a length of at least one cell body diameter. Major neurites were defined as those neurites with the highest length after the computerized measurement of all neurites of a cell, the length difference between this and the smaller neurites being insignificant for this definition. Morphological parameters were quantified with an IBAS image analysis system (Kontron). When tau-immunoreactive neurites were evaluated (see Fig. 5), major neurites were defined as those neurites that were at least 10-20 $\mu \mathrm{m}$ longer than any other neurite of the cell.

The number of neurites per cell, the total neurite length per cell, the length of major neurites per cell, the total length of all minor neurites per cell, and neuronal spreading, defined by the surface area covered by cell body and lamellipodia, but not by neurites or filopodia-like extensions, refer to the population of cells carrying neurites. In each experiment, unless otherwise indicated, 25 cells in each of two wells were analyzed. For determination of the proportion of cells with neurites, 50 neurons in each of two wells were counted per experiment. All graphs comprise data derived from three experiments.

The significance of differences between experimental and control values were analyzed by the following statistical methods. The fraction of neurite-bearing cells was tesled with the T-method, a nonparametric multiple-comparison test. Alternatively, values were arcsine transformed and compared using the unpaired, two-tailed Student's $t$ test, a test for normally distributed variables. Meristic values of the number of neurites per cell were grouped into contingency tables and compared by $\chi^{2}$ analysis. Distributions of total neurite lengths, lengths of major neurites, and total lengths of minor neurites were compared using the Mann-Whitney $U$ test, a nonparametric method. Means of total neurite lengths, lengths of major neurites, total lengths of minor neurites per cell, and the average length of single minor neurites were compared by the Newman-Keuls test, a parametric test less liable to type I errors than the least significant difference test applicd previously (Lochtcr et al., 1991). Means of cell body surface areas and values for adhesion assays were compared using the Newman-Keuls test. All statistical tests were taken from Zar (1974) or Sokal and Rohlf (1981). Student's $t$ tests, $\chi^{2}$ analyses, and Mann-Whitney $U$ tests were performed with the StATVIEW II (Abacus Concepts) program for Macintosh.

\section{Results}

\section{Tenascin affects neurite outgrowth in a manner dependent on} the culture time

The morphological differentiation of hippocampal neurons in polyornithine-coated plastic multiwell tissue culture plates was investigated at $3 \mathrm{hr}$ intervals between 3 and $21 \mathrm{hr}$ in vitro. Aftcr $3 \mathrm{hr}$ in culture, less than $15 \%$ of cells maintained on this substrate (control) had developed neurites (Fig. 1a). The proportion of cells with neurites increased steadily on control substrates until $15 \mathrm{hr}$, when it reached maximal levels with approximately $55 \%$ of all neurons bearing processes (Fig. 1a). The number of neurites per cell, however, increased during the whole culture period (Fig. 1 b). This increase was highest between 9 and $21 \mathrm{hr}$.

When neurons were maintained on tenascin coated onto polyornithine, the proportion of cells with neurites increased only during the first $15 \mathrm{hr}$ of culture, reaching maximal values of about $60 \%$ of all cells bearing neurites, as was the case for cells on polyornithine alone (Fig. 1a). During the first $12 \mathrm{hr}$ of culture the proportion of cells with neurites was significantly higher on 
Table 2. Significance levels of differences between control and test treatments

Time in culture

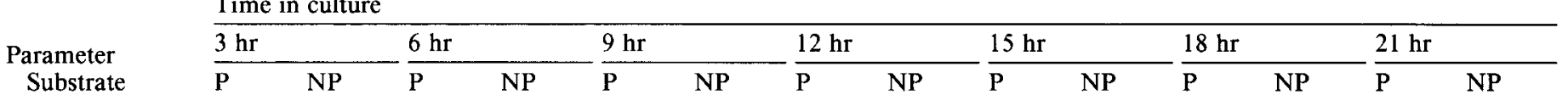

Fraction of cells with neurites

$\begin{array}{llllll}\text { TN } & * * & * * * & * * & * * & * * * \\ \text { LN } & * * * & * * * & * * * & * * * & * * * \\ \text { FN } & * * * & * * * & * * * & * * * & * * * * * * \\ \text { L1 } & * * * & * * * & * * * & * * * & * * * \\ \text { ConA } & * * * & * * * & * * * & * * * & * * *\end{array}$

Number of neurites per cell

$\begin{array}{lll}\text { TN } & * * * & * \\ \text { LN } & * * * & * \\ \text { FN } & * * * & * \\ \text { L1 } & * * * & * \\ \text { ConA } & * * * & *\end{array}$

Total neurite length

\begin{tabular}{|c|c|c|c|}
\hline TN & $* * *$ & $* * *$ & $* * *$ \\
\hline LN & $* * *$ & $* * *$ & $* * *$ \\
\hline $\mathrm{FN}$ & $* * *$ & $* * *$ & $* * *$ \\
\hline Ll & $* * *$ & $* * *$ & $* * *$ \\
\hline ConA & $* * *$ & $* * * *$ & $* * *$ \\
\hline \multicolumn{4}{|c|}{ Length of major neurite } \\
\hline TN & $* *$ & $* *$ & $*$ \\
\hline $\mathrm{LN}$ & $* * *$ & $* * *$ & $* * *$ \\
\hline FN & $* * *$ & $* * *$ & $* * *$ \\
\hline L1 & $* * *$ & $* * *$ & $* * *$ \\
\hline ConA & $* * *$ & $* * *$ & $* * *$ \\
\hline
\end{tabular}

$\begin{array}{ll}* * * & * * * \\ * * & * * * \\ * * * & * * * \\ * * * & * * * \\ * * * & * * *\end{array}$

$\begin{array}{ll}* * & * * \\ * * * & * * * \\ * * & * * *\end{array}$

$* *$
$* * *$
$* * *$
$* * *$

$\begin{array}{ll}\text { NS } & \text { NS } \\ * * & \text { NS } \\ \text { NS } & \text { NS } \\ \text { NS } & \text { NS } \\ \text { NS } & \text { NS }\end{array}$

$\begin{array}{llll}\text { NS } & \text { NS } & \text { NS } & \text { NS } \\ \text { NS } & \text { NS } & \text { NS } & \text { NS } \\ \text { NS } & \text { NS } & \text { NS } & \text { NS } \\ \text { NS } & \text { NS } & \text { NS } & \text { NS } \\ \text { NS } & \text { NS } & \text { NS } & \text { NS }\end{array}$

Total length of minor neurites

$\begin{array}{lllll}\text { TN } & * * * & * * * & * * & * \\ \text { LN } & * * * & * * * & * * & * \\ \text { FN } & * * * & * * * & * * & * \\ \text { L1 } & * * * & * * * & * * * & * \\ \text { ConA } & * * * & * * * & * * * & *\end{array}$

Average length of single minor neurites

$\begin{array}{lll}\text { TN } & \text { NS } & \text { N } \\ \text { LN } & * * & \text { NS } \\ \text { FN } & * & \text { NS } \\ \text { L1 } & * & \text { N } \\ \text { ConA } & * & \\ \text { Spreading } & & * * * \\ \text { TN } & * * * & * \\ \text { LN } & * * * & * \\ \text { FN } & * * * & * * \\ \text { Ll } & * * * & * * \\ \text { ConA } & * * * & \end{array}$

$\begin{array}{lll}\text { NS } & \text { NS } & \text { NS } \\ \text { NS } & \text { NS } & \text { NS } \\ \text { NS } & \text { NS } & \text { NS } \\ \text { NS } & \text { NS } & \text { NS } \\ \text { *** } & \text { NS } & \text { NS } \\ * * * & * * * & \\ * * * & * * * & * * * \\ * * & * * * & * * * \\ * * & \text { NS } & * * * \\ & * & * *\end{array}$

$*$
NS*
NS
NS
***
***
***
NS

$* * *$
$* * *$
$* * *$
$*$
$* *$

$* * *$
$* * *$
NS
$* * *$

$* * *$
$* * *$
$* * *$
NS

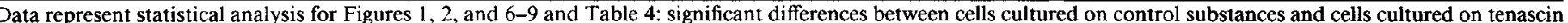

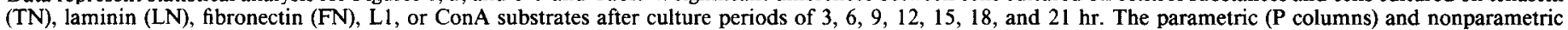

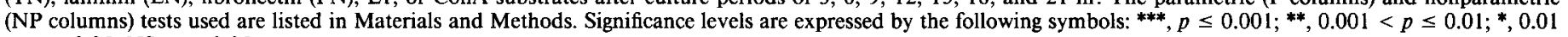
$<p \leq 0.05 ; \mathrm{NS}, p>0.05$.

tenascin than on the control, polyornithine substrate (Fig. la, Table 2). After culture periods of $15 \mathrm{hr}$ the percentage of processbcaring cells on tenascin was not significantly different from the control (Table 2). The number of neurites per cell also increased during the first $12 \mathrm{hr}$ of culture on tenascin (Fig. 1 b) and was significantly higher than under control conditions after 3,6 , and $9 \mathrm{hr}$ (Table 2). After $12 \mathrm{hr}$, in contrast to the control, the numbers of neurites per cell did not increase further, leading to significantly lower values than under control conditions.
Numbers of neurites per cell, when grouped into classes defined by the number of processes per cell (Fig. 1c-e), indicate that after $6 \mathrm{hr}$ of culture on tenascin, about $75 \%$ of the neurons had developed more than one neurite, but only about $50 \%$ of neurons had developed more than one neurite on the control substrate. Distributions of numbers of neurites per cell on control and tenascin substrates after $12 \mathrm{hr}$ were not significantly different (Table 2). After $21 \mathrm{hr}$, most of the cells on tenascin had less than four neurites, whereas most of the neurons had 

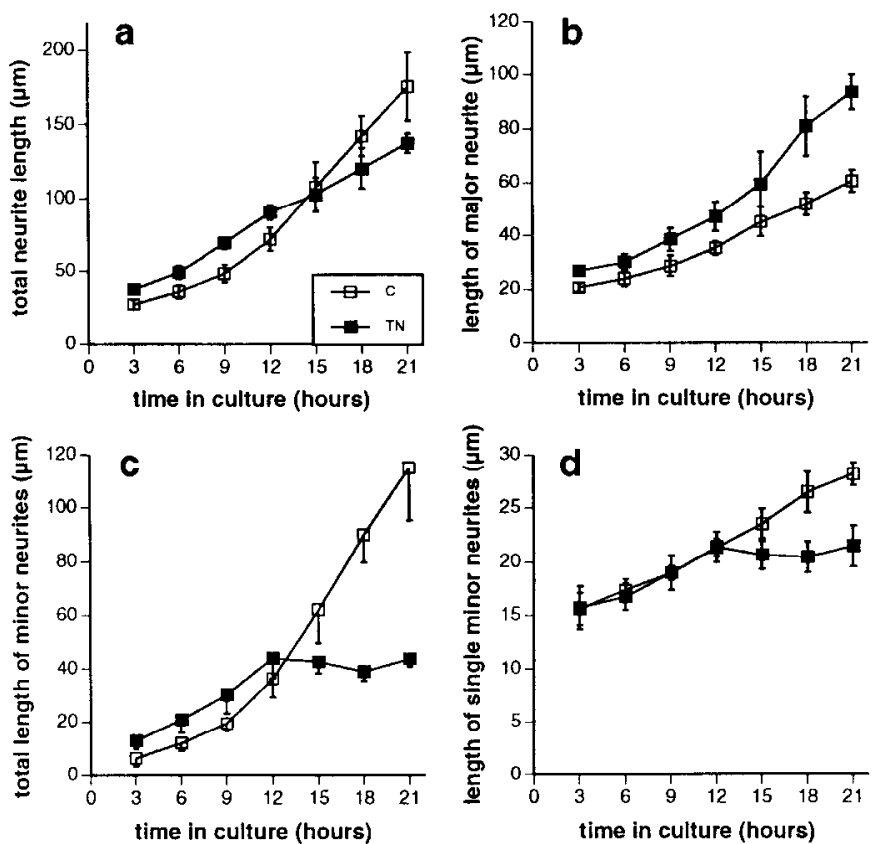

Figure 2. Time dependence of the effects of substrate-bound tenascin on neurite lengths. Cells were maintained for $3,6,9,12,15,18$, and $21 \mathrm{hr}$ in culture, and the length of all neurites of process-bearing cells was measured for neurons on the control substrate ( $C$, open squares) and on tenascin ( $T N$, solid squares). Results show the average lengths per cell of all neurites $(a)$, major neurites $(b)$, all minor neurites $(c)$, and the average length of single minor neurites $(d) \pm \mathrm{SD}$. For significance levels, see Table 2.

more than four neurites on the control substrate. The distributions of numbers of neurites per cell on tenascin were similar at 12 and $21 \mathrm{hr}$, indicating also that the bulk of neurites had reached a steady state. From these data we conclude that between 9 and $12 \mathrm{hr}$ initiation of new neurites ceases on tenascin, but not on the control substrate.

\section{Tenascin affects neurite length, leading to polarization after longer culture periods}

We next analyzed the total length of all neurites per cell (Fig. 2). On the control substrate, the total neurite length increased steadily with time (Fig. $2 a$ ). Small increases in the total neurite length between 3 and $9 \mathrm{hr}$ were followed by a more pronounced growth between 9 and $21 \mathrm{hr}$. To investigate polar growth, that is, asymmetric growth of axonal versus dendritic compartments, the longest neurite of a given cell, the major neurite, was measured separately from the other shorter, the minor neurites, of this cell. Lengths of both major and minor neurites increased with time on the control substrate (Fig. $2 b-d$ ). However, from $9 \mathrm{hr}$ onward, growth of minor neurites was about threefold faster than growth of major neurites. Increases in the total length of minor neurites could be attributed to outgrowth of additional neurites as well as increases in the average length of single minor neurites (Figs. 1b, 2d).

On substrate-bound tenascin, the total neurite length increased between 3 and $21 \mathrm{hr}$ of culture (Fig. $2 a$ ). It was significantly higher than on the control substrate between 3 and 12 $\mathrm{hr}$ and significantly lower after 18 and $21 \mathrm{hr}$ (Table 2). At all times major neurites were, however, significantly longer than on the control substrate (Fig. $2 b$, Table 2). The total length of minor neurites per cell was significantly higher than on the control substrate during the first $9 \mathrm{hr}$ of culture but significantly lower between 15 and $21 \mathrm{hr}$ (Fig. $2 c$, Table 2). The increase in total length of minor neurites on tenascin substrates at early culture periods was solely due to the increase in the number of neurites per cell since the average length of single minor neurites was not different between control and tenascin conditions (Fig. $2 d$ ). Between 12 and $21 \mathrm{hr}$ the average length of minor neurites per cell and the average length of single minor neurites did not increase further. Tenascin thus favored growth of major neurites over growth of minor neurites and therefore increased neuronal polarity at later stages of neuritogenesis. Examples of morphologies of hippocampal neurons on control and tenascin substrates after 6 and $21 \mathrm{hr}$ are shown in Figure 3.

To examine whether the longest neurites are neurites that display the morphological characteristics of major neurites by being substantially longer than the minor neurites, we measured the difference in length between the longest and the second longest neurite. On the control substrate, cells exhibited an average difference of about $20 \mu \mathrm{m}$ between the longest and the second longest neurite when maintained on the control after 21 hr of culture (Table 3 ). On the tenascin substrate, the average length difference between longest and second longest neurite was about $70 \mu \mathrm{m}$. Moreover, only about $40 \%$ and $10 \%$ of cells on the control had major neurites that were more than 20 and 50 $\mu \mathrm{m}$, respectively, longer than the second longest neurite, whereas on tenascin these fractions comprised about $90 \%$ and $70 \%$ for 20 and $50 \mu \mathrm{m}$ longer, respectively. For a succinct illustration of these effects we introduced the polarity index as measure for the relation between major and minor neurites. The polarity index was defined as the average length of major neurites divided by the average length of all minor neurites per cell. The polarity index after $21 \mathrm{hr}$ of culture was about 0.5 for cells on the control substrate and about 2 for cells on the tenascin substrate (Table 3). These data indicate that the total length of all minor neurites per cell was twice as high as the average major neurite on the control substrate, whereas the major neurite was twice as long as the total length of all minor neurites per cell on the tenascin substrate.

To identify the major neurites as axons, cultures were stained by indirect immunofluorescence with antibodies against the microtubule-associated protein tau, which is enriched in axons (Binder et al., 1985; Dotti et al., 1987; Kosik and Finch, 1987). For this purpose we plated the neurons on glass coverslips since in multiwell dishes cultures did not produce reproducible and clear silver-enhanced immunostaining patterns. Neurons cultured on glass differentiated in a similar manner to neurons cultured on tissue culture plastic and, after $21 \mathrm{hr}$, polarized on tenascin (not shown, but see Fig. 4a,c). At 21 hr, tau immunoreactivity could be observed predominantly in the major neurites (Fig. 4).

To characterize further the differences between cells grown on tenascin and cells grown on the control, we quantified the proportion of cells that showed immunoreactivity for the microtubule-associated protein tau in at least one neurite. Only cells with a neurite at least $10-20 \mu \mathrm{m}$ longer than any other of the cell were considered to extend a major neurite. Neurons that expressed tau immunoreactivity in all neurites or only in minor, but not in major, neurites could hardly be detected (Fig. 5). The vast majority of tau-immunoreactive neurons on both substrates showed immunoreactivity only in the major and not in the minor neurites (Fig. 5). On the control substrate about $40 \%$ 

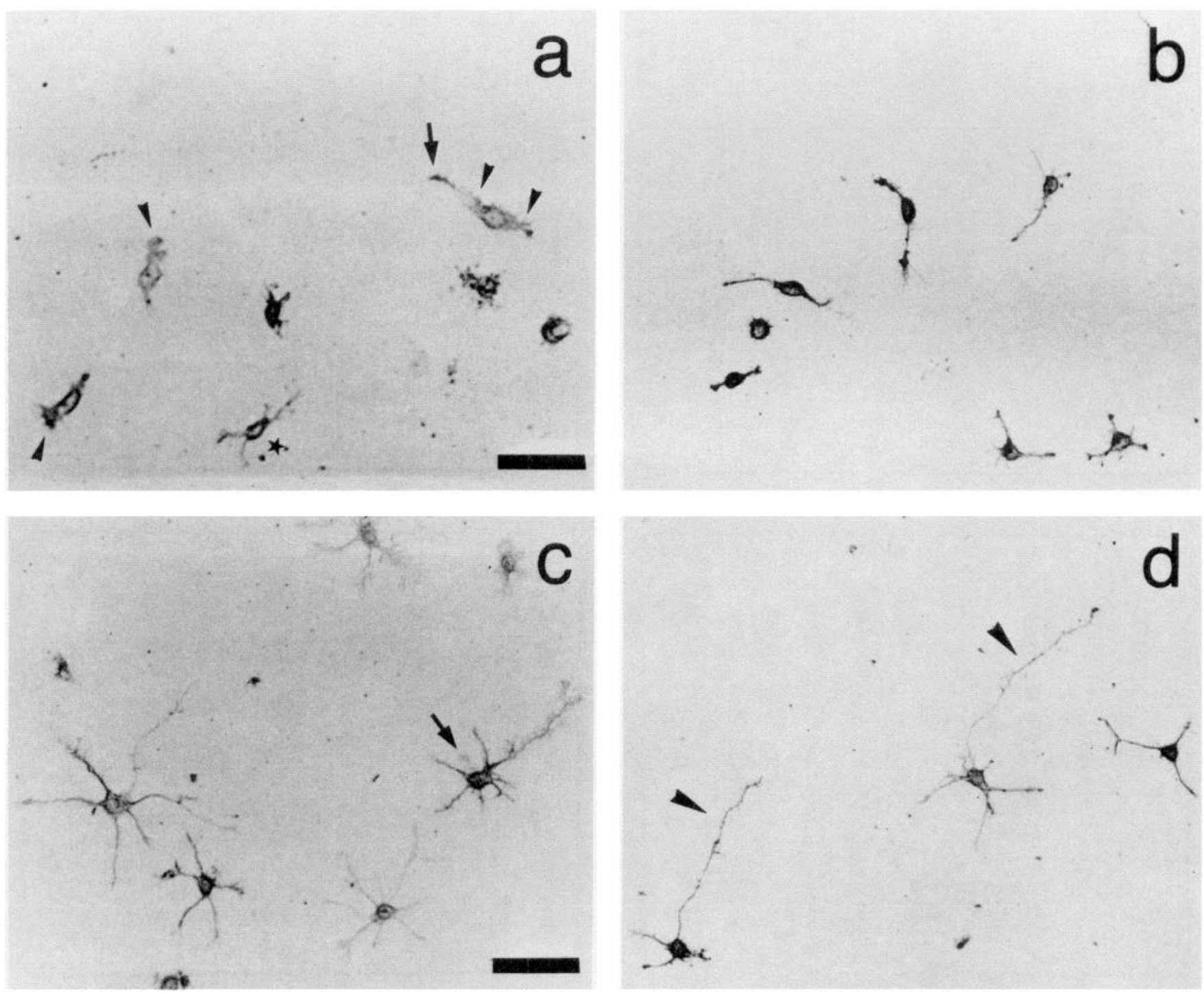

Figure 3. Effects of substrate-bound tenascin on morphologies of hippocampal neurons: bright-field micrographs of hippocampal neurons maintained for $6(a, b)$ and $21(c, d) \mathrm{hr}$ on the control substrate $(a, c)$ and on tenascin $(b, d)$. Cells were visualized by silver-enhanced immunostaining with polyclonal N-CAM antibodies. Cells grown on the control substrate for $6 \mathrm{hr}$ often have well-developed lamellipodia (arrowheads in a) out of which they occasionally start to extend neurites (arrow in a). Only few cells have a morphology similar to that of cells grown on tenascin (star in a). Cells with lamellipodia were rarely found on tenascin substrates after $6 \mathrm{hr}(<10 \%$ of all cells). After $21 \mathrm{hr}$, cells grown on the control substrate develop multiple processes and only occasionally show a polarized phenotype (arrow in $c$ ). Cells grown on tenascin have longer major neurites (arrowheads in $d$ ) and fewer minor neurites. Scale bars, $50 \mu \mathrm{m}$ (for $a-d$ ).

\begin{tabular}{lllll}
\hline Table 3. & Differences between longest and second longest neurite, and polarity index \\
Substrate & $\begin{array}{l}\text { Average } \\
\text { difference }(\mu \mathrm{m})\end{array}$ & $\begin{array}{l}>20 \mu \mathrm{m} \\
\text { (\% of cells) }\end{array}$ & $\begin{array}{l}>50 \mu \mathrm{m} \\
\text { (\% of cells) }\end{array}$ & Polarity index \\
\hline Control & $21.7 \pm 4.23$ & $42 \pm 6.3$ & $9 \pm 3.1$ & $0.54 \pm 0.168$ \\
TN & $69.3 \pm 2.42$ & $93 \pm 1.2$ & $70 \pm 4.7$ & $2.15 \pm 0.215$ \\
LN & $73.5 \pm 9.49$ & $91 \pm 5.6$ & $72 \pm 7.6$ & $3.89 \pm 1.146$ \\
FN & $73.1 \pm 7.63$ & $93 \pm 4.2$ & $75 \pm 4.2$ & $2.23 \pm 0.212$ \\
L1 & $30.2 \pm 3.82$ & $59 \pm 5.1$ & $22 \pm 12.0$ & $0.67 \pm 0.181$ \\
ConA & $27.3 \pm 2.38$ & $55 \pm 6.1$ & $20 \pm 7.9$ & $0.55 \pm 0.154$
\end{tabular}

Data are polarity parameters of hippocampal neurons on different substrates. Hippocampal neurons were maintained for $21 \mathrm{hr}$ on control, tenascin (TN), laminin (LN), fibronectin ( $\mathrm{FN}), \mathrm{Ll}$, and ConA substrates. The difference in length between the longest and the second longest neurite is expressed as the average difference in micrometers (second column) and the proportion of cells of which the longest neurite is more than $20 \mu \mathrm{m}$ (third column) or $50 \mu \mathrm{m}$ (fourth column) longer than the next longest one. The fifth column shows the polarity index obtained by dividing the length of the major neurite by the total length of all minor neurites per cell. All data refer only to cells extending neurites. Values of three experiments are expressed as means \pm SD. For each value about 50 neurons per experiment were analyzed. 

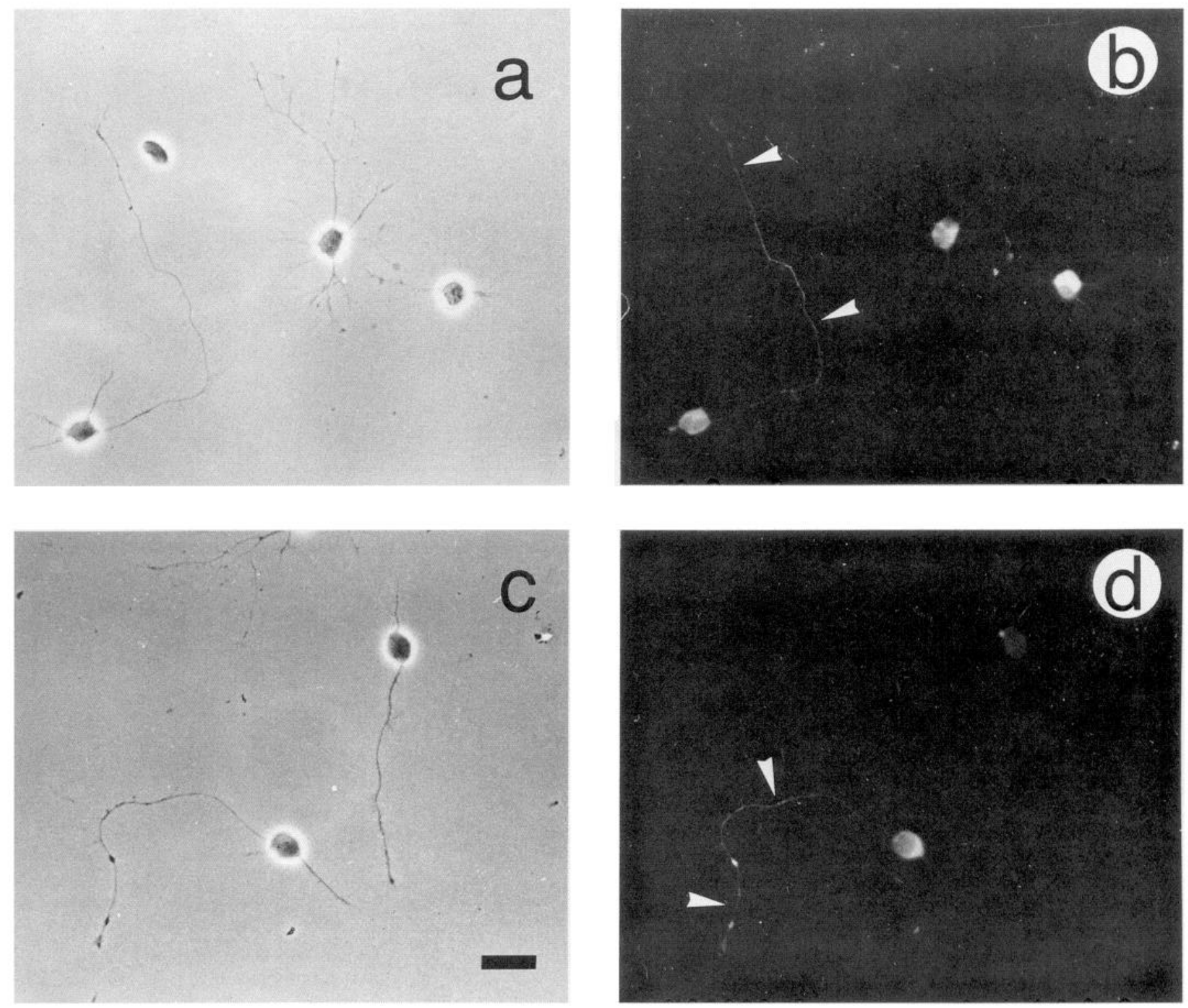

Figure 4. Detection of tau in hippocampal neurons by indirect immunofluorescence. Cells were grown for 21 hr on polyornithine-coated glass coverslips and stained with monoclonal antibodies directed against the microtubule-associated protein tau. Phase-contrast $(a, c)$ and fluorescence $(b, d)$ micrographs show cells cultured on the control substrate $(a, b)$ and on tenascin $(c, d)$. Tau-immunoreactive neurites are marked by arrowheads in $b$ and $d$. Note that only major neurites stained for tau, but not all neurons developed neurites that were tau positive. Scale bar, $20 \mu \mathrm{m}$ for $a-d$.

of all process-bearing cells were tau immunoreactive whereas on tenascin about $75 \%$ of the process-bearing neurons were immunoreactive (Fig. 5). These data indicate that tenascin favors also the biochemical maturation of neuritic compartments.

\section{Substrate-bound laminin and fibronectin also promote neurite outgrowth and subsequent polarization}

To investigate whether induction of outgrowth promotion and subsequent polarization of hippocampal neurons are particular features of tenascin or whether other extracellular matrix glycoproteins have similar properties, laminin and fibronectin were investigated as substrates. Although these two molecules have been shown to promote neurite outgrowth or induce polarization, the temporal sequence of transition from one effect to the other has never been shown in one experiment. On laminin and fibronectin the fraction of neurite-bearing cells was initially increased but later was no longer significantly different from the control (Fig. 6a, Table 2). On fibronectin, the number of neurites per cell was initially increased but then did not increase further, resulting in a decreased number of neurites between 15 and 21 $\mathrm{hr}$ when compared to the control (Fig. $6 b$ ). Correspondingly, the distribution of neurites per cell peaked at higher numbers of neurites than in the control after $6 \mathrm{hr}$ of culture and at lower numbers after $21 \mathrm{hr}$ (Fig. 6c,e). On laminin, the number of neurites per cell did not change significantly between 3 and 21 $\mathrm{hr}$ (Fig. $6 b$; statistical evaluation not shown), resulting in a higher number of neurites than in the control after $6 \mathrm{hr}$ and in a lower number after $21 \mathrm{hr}$ (Fig. $6 b$ ). The distribution of neurite numbers per cell for laminin substrates was very similar for 6,12 , and $21 \mathrm{hr}$ (Fig. $6 c-e$ ). Neurons polarized strongly on both substrates with time in culture (Fig. 7). Total neurite lengths were significantly increased over control values up to $12 \mathrm{hr}$, but significantly decreased at 18 and $21 \mathrm{hr}$ (Fig. 7a, Table 2). Growth of major neurites was faster on laminin and fibronectin than on 


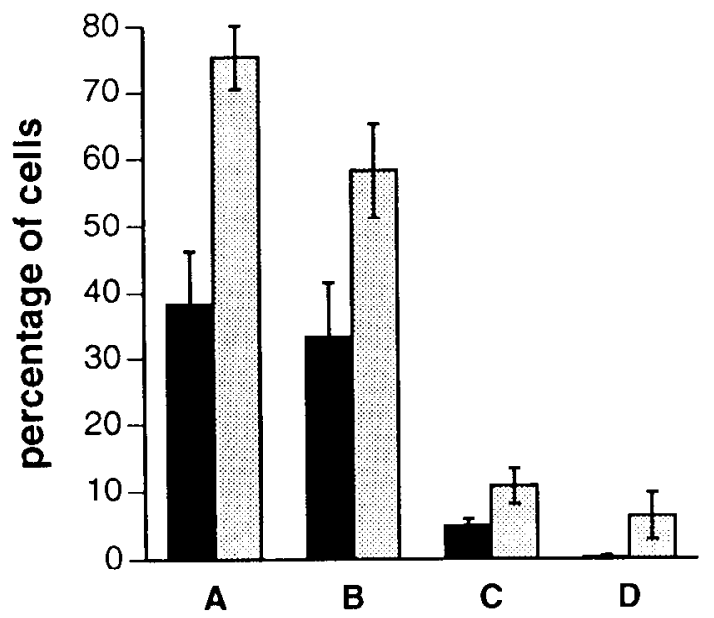

Figure 5. Quantification of tau-immunoreactive cells. Cells were grown for $21 \mathrm{hr}$ on polyornithine-coated glass coverslips and stained with monoclonal antibodies directed against the microtubule-associated protein tau. The number of tau-immunoreactive and nonimmunoreactive cells on control (solid bars) and tenascin (shaded bars) substrates is expressed as the percentage of all counted cells. $A$ shows the percentage of neurons with tau-immunoreactive neurites; $B$, the percentage of neurons with tau immunoreactivity only in the major neurite; $C$, the percentage of neurons with tau immunoreactivity in all neurites; and $D$, the percentage of neurons with tau immunoreactivity in all or a subset of minor neurites but not in the major neurite. Percentages in $B-D$ add up to the value in $A$. Values of three experiments are expressed as means \pm SD. For each value about 100 neurons per experiment were analyzed for tau immunoreactivity.
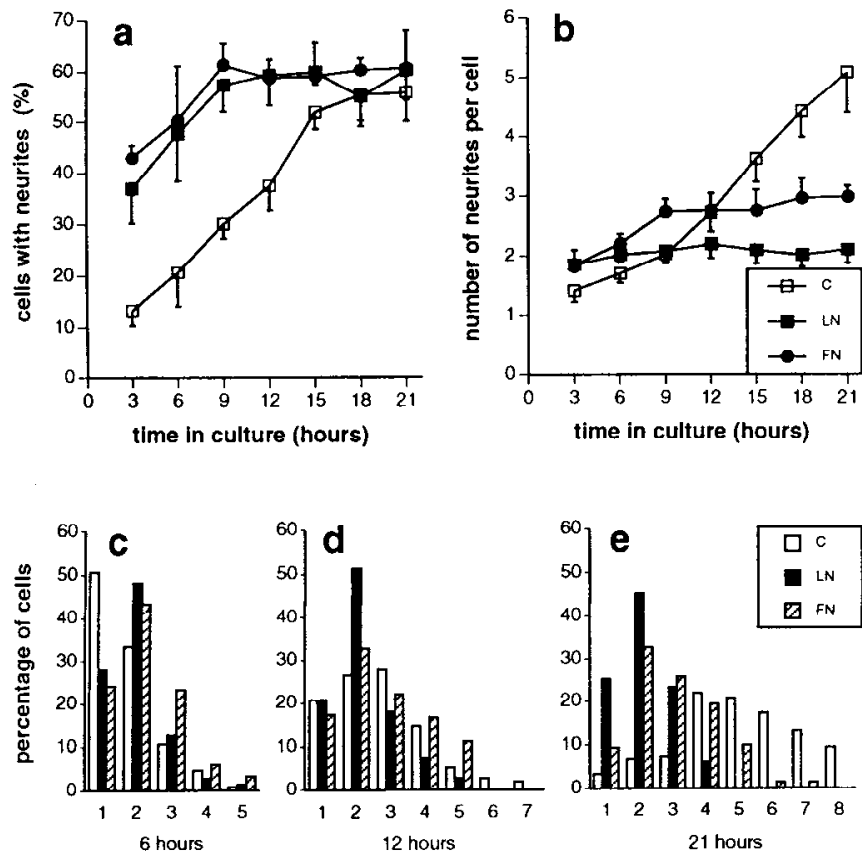

number of neurites per cell

Figure 6. Time dependence of the effects of substrate-bound laminin and fibronectin on the fraction of process-bearing cclls and on the average number of neurites per cell. Cells were maintained for $3,6,9,12$, 15,18 , and $21 \mathrm{hr}$ in culture and the proportion of cells with neurites $(a)$ and the number of neurites per cell $(b)$ were counted. Results are shown with means $\pm \mathrm{SD}$ for neurons on the control substrate $(C$, open squares), on laminin ( $L N$, solid squares), and on fibronectin ( $F N$, solid circles). Distributions of the number of neurites per cell are shown for $6(c), 12(d)$, and $21(e) \mathrm{hr}$ for neurons on the control substrate (open hars), on laminin (solid bars), and on fibronectin (hatched bars). Neuron populations in $c-e$ are the same as in $b$ for 6,12 , and $21 \mathrm{hr}$. For significance levels, see Table 2 .
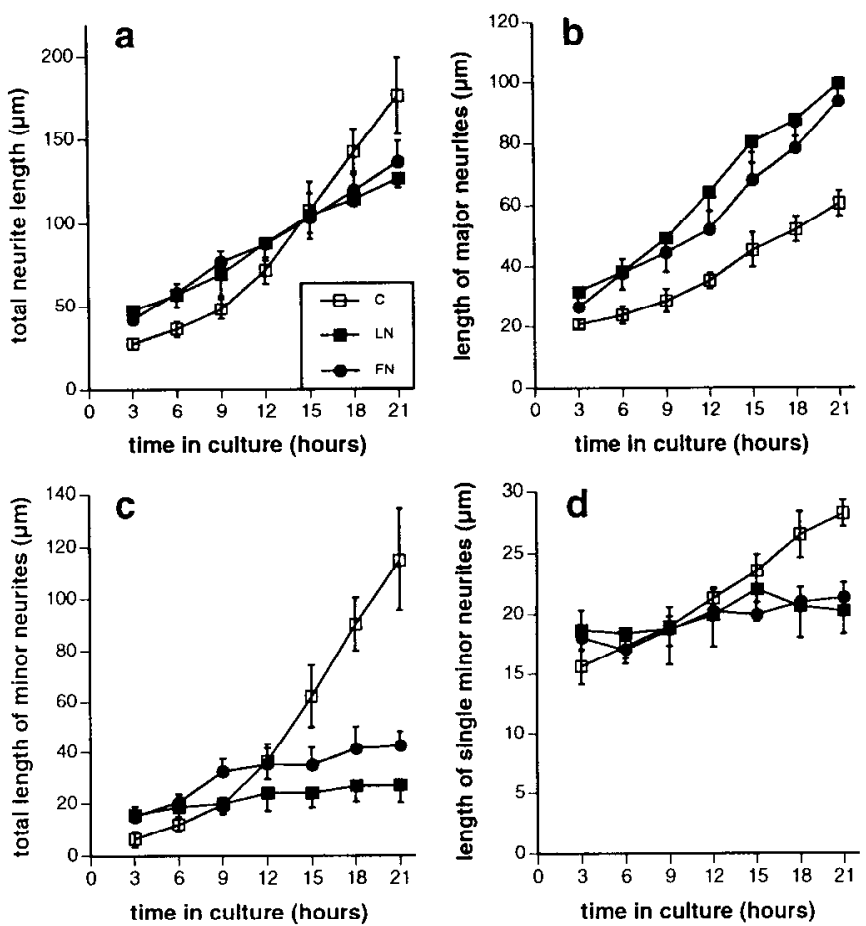

Figure 7. Time dependence of the effects of substrate-bound laminin and fibronectin on neurite lengt'ns. Cells were maintained for $3,6,9$, $12,15,18$, and $21 \mathrm{hr}$ in culture and the length of all neurites of processbearing cells was measured for neurons on the control substrate $(C$, open squares), on laminin ( $L N$, solid squares), and on fibronectin ( $F N$, solid circles). Results show the average lengths per cell of all neurites $(a)$, major neurites $(b)$, all minor neurites $(c)$, and the average length of single minor neurites $(d), \pm \mathrm{SD}$. For significance levels see Table 2 .

the control at all time points examined (Fig. $7 b$ ) and most of the major neurites were more than $50 \mu \mathrm{m}$ longer than the next longest neurite after $21 \mathrm{hr}$ of culture (Table 3 ). The average length of all minor neurites per cell on fibronectin substrates clearly increased between 3 and $9 \mathrm{hr}$ (Fig. 7c), whereas on laminin only marginal increases in the total lengths of minor neurites per cell were noticed between 3 and $21 \mathrm{hr}$ (Fig. 7c). Also, the average length of single minor neurites increased only slightly on laminin and fibronectin substrates (Fig. $7 d$ ). As judged by the polarity index, laminin increased polarity more than the other extracellular matrix molecules examined (see Fig. 10 for examples of neuronal morphologies).

\section{The cell adhesion molecule $L 1$ and the lectin ConA promote neurite outgrowth but do not increase polarity}

On Ll or ConA, initial neurite outgrowth was increased as indicated by an augmentation of the fraction of process-bearing cells during the first $9 \mathrm{hr}$ (Fig. 8a). After $15 \mathrm{hr}$, however, the percentage of process-bearing cells did not differ significantly from the control (Table 2). Mean values and distributions of the number of neurites per cell were higher on both substrates than on the control at all times examined (Fig. $8 b-e$ ). The average lengths of major and all minor neurites per cell were also increased over control values at all times studied (Fig. 9b,c), resulting in total neurite lengths higher than on the control at all time points (Fig. 9a). As shown in Table 3, a slight increase in the difference between the length of the longest neurite and the length of the next longest neurite of a cell could be detected on $\mathrm{L} 1$ and ConA substrates after $21 \mathrm{hr}$ of culture. This increase 

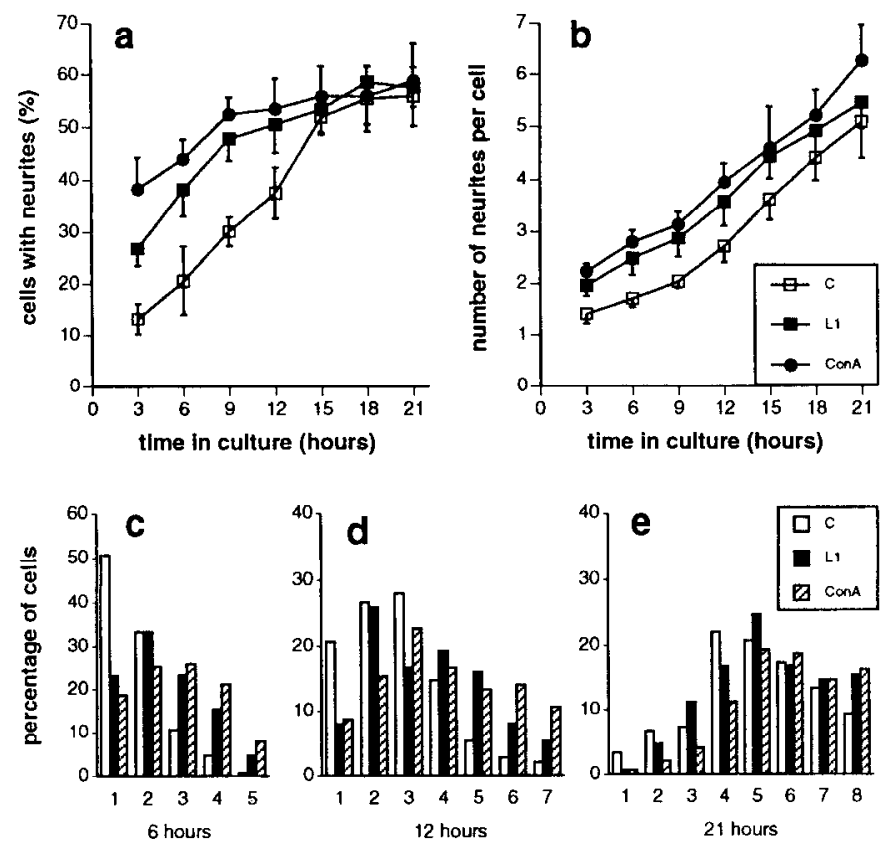

number of neurites per cell

Figure 8. Time dependence of the effects of substrate-bound L1 and ConA on the fraction of process-bearing cells and on the average number of neurites per cell. Cells were maintained for $3,6,9,12,15,18$, and $21 \mathrm{hr}$ in culture and the proportion of cells with neurites $(a)$ and the number of neurites per cell $(b)$ were counted. Results are shown with means $\pm \mathrm{SD}$ for neurons on the control substrate (C, open squares), on Ll (solid squares), and on ConA (solid circles). Distributions of the number of neurites per cell are shown for $6(c), 12(d)$, and $21(e)$ hr for neurons on the control substrate (open bars), on L1 (solid bars), and on ConA (hatched bars) substrates. Neuron populations in c-e are the same as in $b$ for 6,12 , and $21 \mathrm{hr}$. For significance levels, see Table 2.

was much lower than for the extracellular matrix molecules and the polarity index was not different from the control. Therefore, the overall morphology of neurons maintained under L1, ConA, and control conditions was similar (see Fig. 10 for examples of neuronal morphologies). At $21 \mathrm{hr}$, means for the total length of minor neurites per cell were only slightly, and not significantly, higher on L1 than on control substrates, although statistical analysis of ranked values did result in significant differences indicating that length distributions are different for control and Ll substrates (Table 2).

\section{Neuronal spreading and adhesion are strongly reduced on all extracellular matrix substrates}

To relate neurite outgrowth and polarization to neuron-to-substrate adhesion, we measured the extent of spreading (Table 4) and the strength of adhesion of hippocampal neuron cell bodies to the substrate (Table 5). Spreading of cell bodies, as defined by the surface area covered by the cell bodies of process-bearing cells, increased with time on the control substrate from about $120 \mu \mathrm{m}^{2}$ after $3 \mathrm{hr}$ to about $160 \mu \mathrm{m}^{2}$ after $21 \mathrm{hr}$ of culture. When cell populations comprising both process-bearing and non-process-bearing cells on the control substrate were examined, spreading after $3 \mathrm{hr}$ was higher than $120 \mu \mathrm{m}^{2}$ and decreased with time (not shown), suggesting that cells without neurites often develop lamellipodial halos that withdraw when neurites start to develop (Figs. 3, 4; see also Banker and Cowan, 1977; Dotti et al., 1988; Lochter et al., 1991). Spreading was reduced
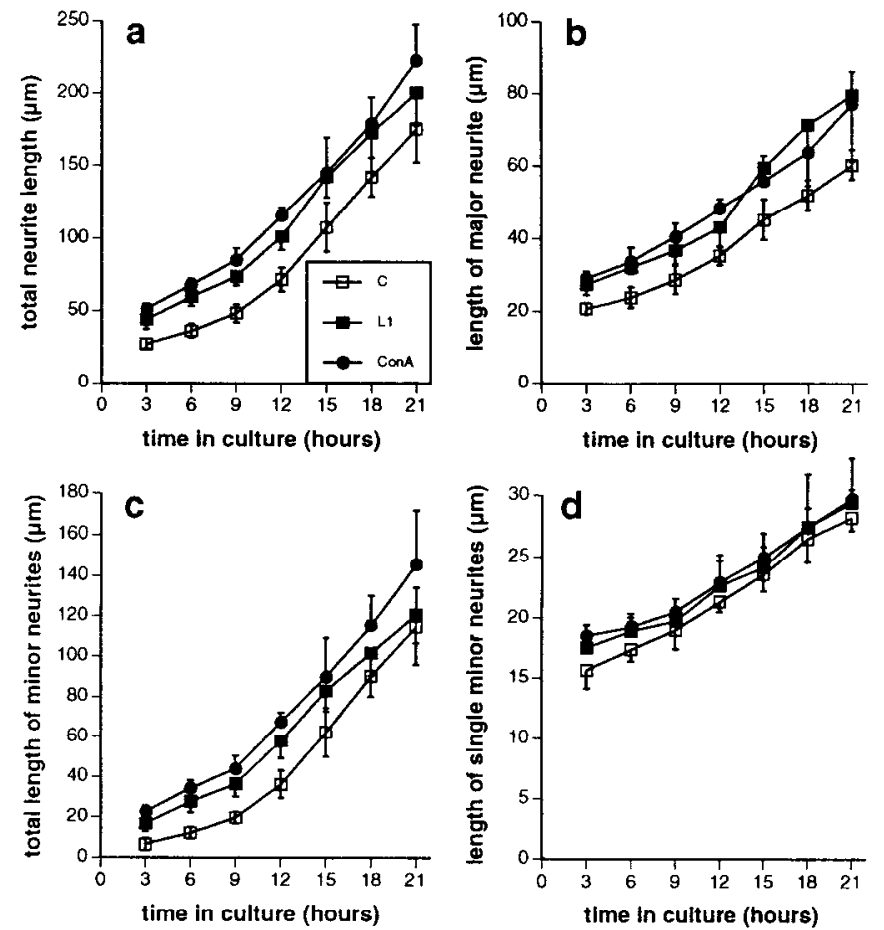

Figure 9. Time dependence of the effects of $\mathrm{Ll}$ and ConA on neurite lengths. Cells were maintained for $3,6,9,12,15,18$, and $21 \mathrm{hr}$ in culture, and the length of all neurites of process-bearing cells was measured in three experiments for neurons on the control substrate $(C$, open squares), on LI (solid squares), and on ConA (solid circles). Results show the average lengths per cell of all neurites $(a)$, major neurites $(b)$, all minor neurites $(c)$, and the average length of single minor neurites $(d)$ $\pm \mathrm{SD}$. For significance levels, see Table 2 .

by approximately $50 \%$ on tenascin, laminin, and fibronectin, when compared to the control, at all time points studied. A significant reduction of spreading on Ll was also observed (Table 2). The smallest reduction of spreading was seen on ConA and was significant only before $12 \mathrm{hr}$ (Table 2 ).

Adhesion strength of cell bodies to their substrates was determined by shaking the multiwell plates after 3 and $21 \mathrm{hr}$ of culture and counting the number of adhered cells (Table 5). Adhesion to tenascin and laminin was strongly reduced when compared to the control substrate. Adhesion to fibronectin was also reduced, but less markedly than on tenascin and laminin. Adhesion to L1 or ConA was not different from the control.

\section{Discussion}

In this article we describe the effects of the extracellular matrix glycoproteins tenascin, laminin, and fibronectin, the cell adhesion molecule L1, and the lectin ConA on the morphological differentiation of hippocampal neurons in vitro. A summary of the results is shown in a schematic representation (Fig. 11).

Our main observations are the following. (1) Growth of hippocampal neurons on extracellular matrix substrates results in increased total neurite lengths after short culture periods, compared to the control substrate polyornithine. (2) With ongoing morphological differentiation total neurite lengths on extracellular matrix substrates become reduced compared to the control. (3) Decreases in total neurite lengths on extracellular matrix substrates are due to an arrest of growth of minor neurites, but major neurites grow faster on extracellular matrix than on con- 

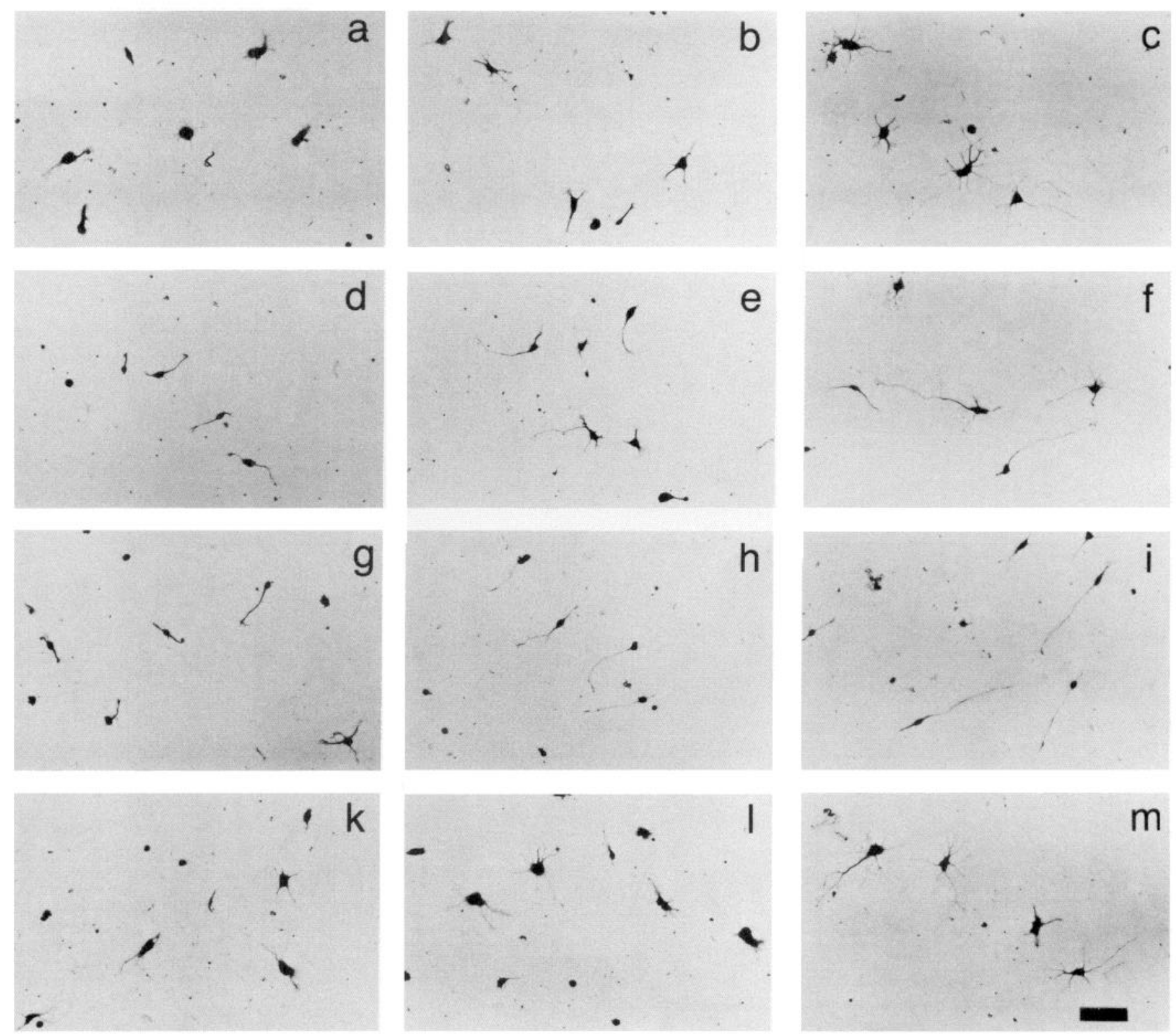

Figure 10. Morphologies of hippocampal neurons on control, tenascin, laminin, and L1 substrates after various times in culture: bright-field micrographs of toluidine blue stained hippocampal neurons on control $(a-c)$, tenascin $(d-f)$, laminin $(g-i)$, and L1 $(k-m)$ substrates after $6(a, d$, $g, k), 12(b, e, h, l)$, and $21(c, f, i, m)$ hr in culture. After $6 \mathrm{hr}$, cells have extended more neurites on tenascin, laminin, and Ll substrates than on the control substrate. After $21 \mathrm{hr}$, cells on the control substrate and on L1 have developed a complex morphology and multiple neurites. On tenascin and laminin substrates, the reduction in length of minor neurites in comparison to control and L1 substrates is evident after $21 \mathrm{hr}$ and is more pronounced with cells cultured on laminin.

trol substrates. Correspondingly, neuronal polarity is increased. (4) The effects of the extracellular matrix molecules tenascin, laminin, and fibronectin are different from the effects of $\mathrm{L} 1$ and ConA, which do not increase neuronal polarity.

Hippocampal neurons maintained for 3-9 $\mathrm{hr}$ on tenascin, laminin, or fibronectin showed an increase in the percentage of process-bearing cells, the number of neurites per cell, and the total neurite length per cell, when compared to the control substrate. These results are in agreement with previous observations describing the neurite outgrowth-promoting activity of these molecules (e.g., Akers et al., 1981; Manthorpe et al., 1983; Rogers et al., 1983; Wehrle and Chiquet, 1990; Lochter et al., 1991).

When cells were maintained for $18-21 \mathrm{hr}$, substrate-coated tenascin, laminin, and fibronectin caused a decrease in the total neurite length per cell in comparison to the control substrate. However, the length of the longest, the major neurite, was higher on all three extracellular matrix substrates. The length and number of the shorter neurites, the minor neurites, were reduced. Correspondingly, the average difference in length between the longest and the next longest neurite was strongly increased. Therefore, all three extracellular matrix molecules tested increased neuronal polarity.

In agreement with the notion that major neurites resemble premature axons, major neurites were immunoreactive for the microtubule-associated protein tau and minor neurites were only occasionally immunoreactive. The doubly increased percentage of tau-immunoreactive cells on tenascin compared to control 
Table 4. Spreading of cell bodies on different substrates

\begin{tabular}{|c|c|c|c|c|c|c|c|}
\hline \multirow{2}{*}{$\begin{array}{l}\text { Sub- } \\
\text { strate }\end{array}$} & \multicolumn{7}{|l|}{ Cell body area } \\
\hline & $\overline{3 \mathrm{hr}}$ & $6 \mathrm{hr}$ & $9 \mathrm{hr}$ & $12 \mathrm{hr}$ & $15 \mathrm{hr}$ & $18 \mathrm{hr}$ & $21 \mathrm{hr}$ \\
\hline Control & $118.4 \pm 19.87$ & $111.3 \pm 24.4$ & $119.5 \pm 24.1$ & $128.6 \pm 13.2$ & $134.7 \pm 23.26$ & $146.0 \pm 14.68$ & $157.8 \pm 21.95$ \\
\hline $\mathrm{TN}$ & $65.4 \pm 11.67$ & $68.2 \pm 14.52$ & $71.0 \pm 14.18$ & $81.9 \pm 11.03$ & $82.0 \pm 6.95$ & $83.5 \pm 9.89$ & $79.0 \pm 14.99$ \\
\hline $\mathrm{LN}$ & $62.8 \pm 6.50$ & $61.2 \pm 11.04$ & $65.8 \pm 8.68$ & $65.5 \pm 11.50$ & $75.6 \pm 10.42$ & $80.2 \pm 5.97$ & $74.7 \pm 4.76$ \\
\hline FN & $69.3 \pm 4.45$ & $71.6 \pm 7.11$ & $78.0 \pm 8.91$ & $83.8 \pm 7.14$ & $80.7 \pm 19.58$ & $82.8 \pm 11.68$ & $87.0 \pm 5.68$ \\
\hline $\mathbf{L} 1$ & $101.4 \pm 13.29$ & $96.5 \pm 17.51$ & $108.5 \pm 16.69$ & $109.8 \pm 6.13$ & $127.8 \pm 14.26$ & $133.1 \pm 8.64$ & $130.6 \pm 9.32$ \\
\hline ConA & $96.9 \pm 5.95$ & $99.0 \pm 8.64$ & $109.4 \pm 7.66$ & $120.2 \pm 10.50$ & $126.4 \pm 13.34$ & $145.2 \pm 22.08$ & $144.9 \pm 14.86$ \\
\hline
\end{tabular}

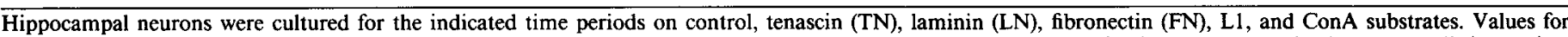

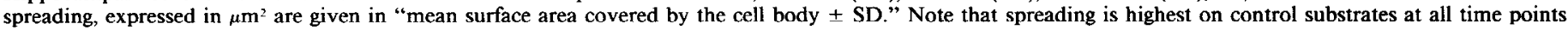
investigated. For statistics and significance levels, see Table 2.

substrates indicates that tenascin induces not only the morphological polarization but also the biochemical compartmentalization of neurons. Although tau was reported to be present in both major and minor neurites of hippocampal neurons (Dotti et al., 1987), a more prominent staining in major ncurites than in minor neurites during phases of elongation of the major neurite was observed. Exclusive staining of axons, but not of dendrites, in culture has been described for cerebral cortical neurons (Kosik and Finch, 1987). Immunostaining of hippocampal cultures on control and tenascin substrates after $21 \mathrm{hr}$ of culture with antibodies against MAP2 and GAP-43 revealed that these markers were not convincing indicators of polarity, since MAP2 positivity of minor neurites was seen only with less than $50 \%$ of process-bearing neurons and GAP-43 was only occasionally detected preferentially in growth cones of major compared to minor neurites (A. Lochter and M. Schachner, unpublished observations). However, these latter results are not unsuspected since MAP2 has been found compartmentalized only after several days in culture (Caceres et al., 1986; Chamak and Prochiantz, 1989), and GAP-43 was described as enriched, but not exclusively expressed, in major neurites of early stage 3 neurons (Goslin et al., 1990).

We were not able to follow the morphological differentiation of hippocampal neurons for more than $1 \mathrm{~d}$ since the cells started to degenerate at longer culture periods. However, the morphology of neurons on extracellular matrix substrates after 21 hr clearly resembled that of stage 3 neurons (Dotti et al., 1988), which is characterized by growth arrest of minor neurites and continued growth of major neurites: about $70 \%$ of all neurite-

Table 5. Adhesion assay

Number of neurons adhered

\begin{tabular}{lrr} 
& \multicolumn{2}{l}{ Number of neurons adhered } \\
\cline { 2 - 3 } Substratc & \multicolumn{1}{c}{$3 \mathrm{hr}$} & \multicolumn{1}{c}{$21 \mathrm{hr}$} \\
\hline Control & $40.3 \pm 4.38$ & $37.8 \pm 5.34$ \\
TN & $4.1 \pm 2.13$ & $9.4 \pm 4.99$ \\
LN & $12.3 \pm 3.96$ & $10.7 \pm 5.68$ \\
FN & $25.7 \pm 8.69$ & $21.9+6.97$ \\
Ll & $43.1 \pm 5.32$ & $41.4 \pm 8.43$ \\
ConA & $43.6 \pm 5.10$ & $40.0 \pm 9.63$
\end{tabular}

Data are from adhesion assay for hippocampal neurons on different substrates. Hippocampal neurons were cultured for 3 and $21 \mathrm{hr}$ in multiwell plates on control, tenascin (TN), laminin (LN), fibronectin (FN), L1, and ConA substrates. They were then mechanically agitated for $5 \mathrm{~min}$. The average numbers of adhered cells per visual field \pm SD are shown. Adhesion of neurons to tenascin, laminin, and fibronectin, when compared with the Newman-Keuls test, was found to be significantly different from adhesion to control substrates $(p \leq 0.001)$, whereas adhesion of neurons to Ll or ConA was not $(p>0.05)$. bearing cells on extracellular matrix substrates had major neurites that were more than $50 \mu \mathrm{m}$ longer than the next longest neurite and neither the number nor the length of minor neurites increased during the last hours of culture. Neurons grown on

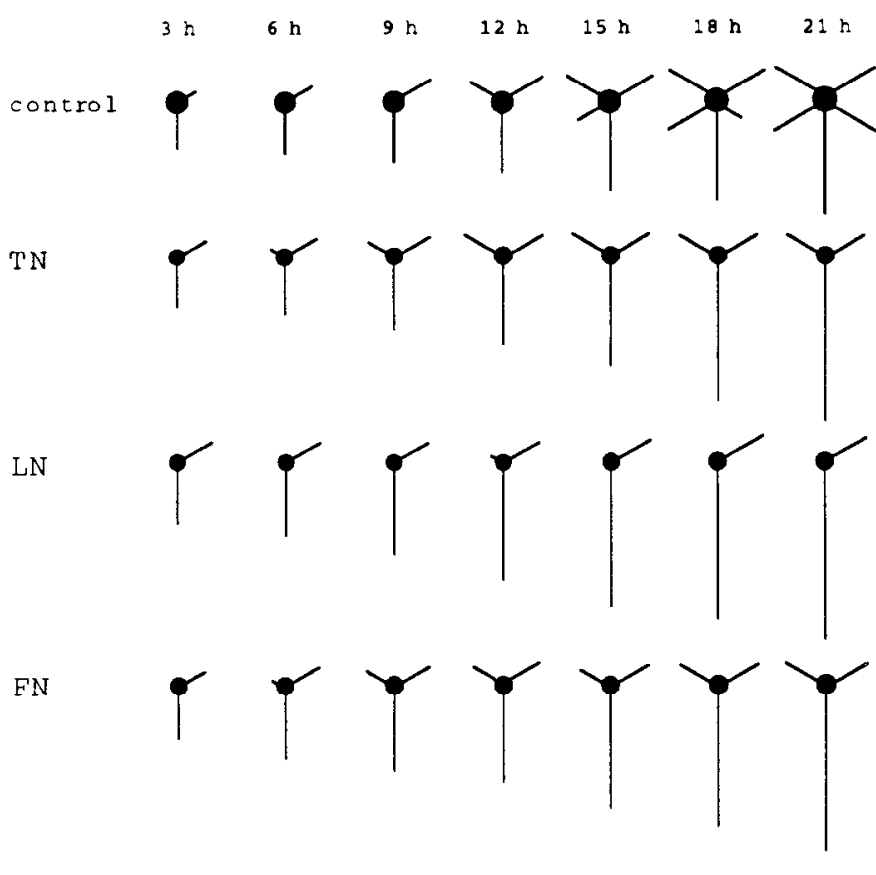

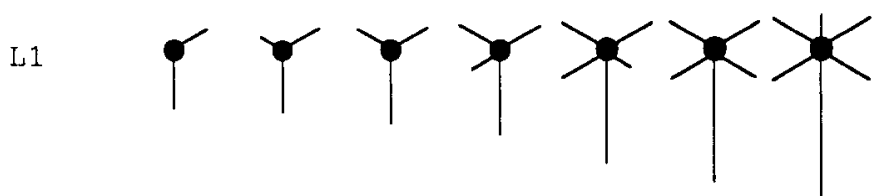

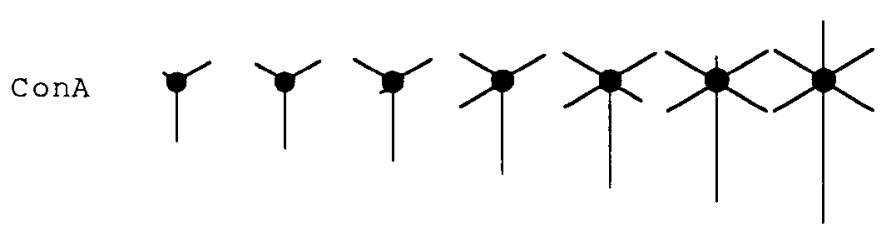

Figure 11. Schematic drawings of morphologies of hippocampal neurons for the different culture times and substrates: true-to-scale drawings of hippocampal neurons on control, tenascin $(T N)$, laminin $(L N)$, fibronectin $(F N), \mathbf{L} 1$, and ConA substrates, according to means from Figures 1, 2, and 6-9, and Table 4. Cell body spreading is represented by the solid circle. Major neurites are drawn downward from the cell body. Other neurites represent minor neurites. Note that at all times and on all substrates the major neurites increase in length. The minor neurites increase continuously in length on $\mathrm{Ll}$ and ConA but cease to grow on extracellular matrix substrates between 3 and $12 \mathrm{hr}$. 
the control substrate did not obviously match any of the developmental stages described by Banker and colleagues (Dotti et al., 1988). Minor neurites of our cells frequently exceeded 30 $\mu \mathrm{m}$ in length, whereas classical stage 2 and 3 neurons were reported to have minor neurites less than $20 \mu \mathrm{m}$ in length (Banker and Cowan, 1977; Dotti et al., 1988). It appears likely to us that the differences in culture conditions account for the described differences in growth behavior. Banker and colleagues maintained their cells after plating for several hours in serumcontaining medium and afterward in the presence of astrocytes. Since serum contains and astrocytes express and secrete extracellular matrix molecules including tenascin, laminin, and fibronectin (Hynes and Yamada, 1982; Liesi et al., 1983, 1986; Kruse et al., 1985), these molecules may lead to an arrest of growth of minor neurites in the cultures of Banker and colleagues. We therefore propose that in the absence of extracellular matrix molecules growth of minor neurites of hippocampal neurons does not cease before the onset of morphological polarization, but continues while the major neurite starts to elongate faster than the remaining neurites.

Polarizing activities of laminin for mesencephalic (Chamak and Prochiantz, 1989), hippocampal (Lein et al., 1992), and sympathetic neurons (Lein and Higgins, 1989) and of fibronectin for mesencephalic neurons (Chamak and Prochiantz, 1989) have been described. The present article, however, is the first description that tenascin induces polarity in neurons. With our observation of the polarizing activity of tenascin and recent findings that collagen IV, thrombospondin, proteoglycans, and glycosaminoglycans all promote growth of axons, but not dendrites (Lein et al., 1991; Lafont et al., 1992; Osterhout et al., 1992), a common functional feature of extracellular matrix molecules becomes apparent. In contrast to the effects of substratebound tenascin, tenascin added in soluble form to the culture medium inhibits growth not only of minor, but also of major neurites (Lochter et al., 1991; Lochter and Schachner, unpublished observations). Mesencephalic neurons have been shown to respond to the addition of soluble laminin with increased growth of major and decreased growth of minor ncurites, whereas soluble fibronectin had only marginal effects on the neuronal morphology (Chamak and Prochiantz, 1989). When we added soluble laminin or fibronectin to hippocampal cultures, we observed, depending on the concentration used, either no effect or an increase in neuronal polarity similar to the effects of the substrate-bound molecules (Lochter and Schachner, unpublished observations). We conclude from these observations that inhibition of growth of major and minor neurites is specifically induced by soluble tenascin and not by laminin or fibronectin in either substrate-bound or soluble form.

The kinetic analysis of the establishment of neuronal polarity on extracellular matrix substrates shows for the first time that increased neuronal polarity on extracellular matrix substrates is preceded by a phase of increased neurite outgrowth. This feature is again shared by tenascin, laminin, and fibronectin, but the onset of polarization occurred carlicr on laminin than on tenascin or fibronectin substrates. Our results show that on tenascin, laminin, and fibronectin growth of minor neurites ceased within the first $12 \mathrm{hr}$ of culture, and only the major neurite continued to grow, thus solely accounting for the increase in total neurite length after longer culture periods. The time window in which increased neurite outgrowth precedes polarization appears to depend not only on the substrate-coated molecules but also on the physical properties of the carrier used for coating. In a previous study, hippocampal neurons were cultured on tenascin in chamber slides (Lochter et al., 1991) and did not extend neurites as quickly as in the present study. When absolute neurite lengths of both studies are compared, total neurite length on the control substrate was about $100 \%$ higher in the present study after $21 \mathrm{hr}$ when compared to the former after $24 \mathrm{hr}(175$ $\mu \mathrm{m}$ vs $83 \mu \mathrm{m}$ ). The morphology of cells after $12 \mathrm{hr}$ in the present study resembled that of cells cultured for $24 \mathrm{hr}$ in the former study. Both studies are therefore in agreement in that substratebound tenascin, laminin, and fibronectin increase growth of major and minor neurites in the initial phase of neurite outgrowth.

It has been postulated that the establishment of neuronal polarity is correlated with a reduction of cell body spreading and neuron-to-substrate adhesion (Chamak and Prochiantz, 1989). We have shown that the neurite outgrowth-inducing activity of substrate-bound tenascin is also correlated with decreased spreading and adhesion of neurons (Lochter et al., 1991). We presented evidence that neuronal spreading and neuron-tosubstrate adhesion are strongly reduced on tenascin, laminin, and fibronectin during the period of increased neurite outgrowth as well as during the period of polarization. Therefore, tenascin, laminin, and fibronectin act as antiadhesive molecules for CNS neurons when grown on an adhesive substrate, such as polyornithine. Growth of retinal ganglion cell neurites on substrates composed of polylysine and laminin was also correlated with decreased growth cone adhesion compared to polylysine alone (Lemmon et al., 1992). Furthermore, migration of olfactory neurons on a mixed laminin-fibronectin substrate was faster than on a fibronectin substrate alone and was associated with a reduced adhesion of cell bodies (Calof and Lander, 1991). These examples support the notion that extracellular matrix glycoproteins are antiadhesive molecules on otherwise adhesive substrates. On the other hand, laminin and fibronectin, but not tenascin, are adhesive and neurite outgrowth promoting in combination with neutral substrates, such as albumin (e.g., Manthorpe et al., 1983; Rogers et al., 1983; Liesi et al., 1984; Hall ct al., 1987; Faissner and Kruse, 1990; Lochter and Schachner, unpublished observations). Moreover, soluble tenascin, which, unlike soluble laminin or fibronectin, inhibits neurite outgrowth of both major and minor neurites, reduces cell body spreading and adhesion on polyornithine (Lochter et al., 1991). Thus, the molecules appear to act depending on their environment and despite several functional similarities certain distinctive features cannot be overlooked.

Neurite outgrowth promotion does not inevitably result in subsequent polarization, as we could show by use of substratecoated L1 and ConA. L1-dependent promotion of neurite outgrowth and elongation has been described for cerebellar (Lagenauer and Lemmon, 1987; Lemmon et al., 1989), tectal (Lagenauer and Lemmon, 1987), retinal (Lemmon et al., 1992), sympathetic (Chang et al., 1990), ciliary ganglion (Bixby and Jhabvala, 1990), and dorsal root ganglion neurons (Kuhn et al., 1991). Also, substrate-coated ConA was reported to increase neurite outgrowth (e.g., DeGeorge et al., 1985; DeGeorge and Carbonetto, 1986; Lin and Levitian, 1991). We could show that, in contrast to extracellular matrix substrates, L1 promoted growth of major and minor neurites and did not increase neuronal polarity. In situ, $\mathrm{Ll}$ is expressed on axons but not on dendrites (Fushiki and Schachner, 1986; Persohn and Schachner, 1987, 1990; Godfraind et al., 1988). In vitro, however, L1 is expressed on both major and minor neurites after $1 \mathrm{~d}$ of culture (Lochter 
and Schachner, unpublished observations). Since L1 mediates neurite outgrowth at least in part via a homophilic binding mechanism (Lemmon et al., 1989; Kadmon et al., 1990a,b; Kuhn et al., 1991), expression of $\mathrm{Ll}$ on both major and minor neurites in vitro is consistent with the promotion not only of axonal but also of dendritic growth. ConA interacts with oligomannosidic carbohydrate epitopes on glycoproteins and glycolipids and has multiple effects on neuronal morphology and physiology (for review, see Lin and Levitian, 1991; Mironov, 1992). It also binds to cell adhesion molecules, for example, L1 and N-CAM, present on major and minor neurites of hippocampal neurons, thereby possibly mimicking the effects of the natural ligands of these adhesion molecules. I hese results indicate that $\mathrm{Ll}$ and Con $\mathrm{A}$ increase neurite outgrowth without increasing ncuronal polarity, whercas the less adhesive cxtracellular matrix glycoproteins tenascin, laminin, and fibronectin promote neurite outgrowth and subsequently increase polarity.

We would finally like to relate our observations to the possible functions of tenascin in the spatiotemporal pattern of its expression in vivo. When offered as a uniform substrate in vitro, tenascin promotes neurite growth and selectively favors growth of major over growth of minor neurites when offered as a substrate boundary, it inhibits growth of axums ( 1 aylul et al., 1993). Two structures of the mouse brain, the cerebellum and the somatosensory cortex, may illustrate these two different functions of tenascin (Steindler et al., 1989; S. Bartsch et al., 1992). In both brain regions tenascin expression is high only during a restricted time period of development, when functional connections are being established. In the cerebellum, tenascin is uniformly associated with granule cell axons when they extend in the molccular laycr (S. Bartsch et al., 1992). In this situation tenascin could act as an accelerator of axonal elongation. In the somatosensory cortical barrel field (Woolsey and Van Der Loos, 1970), tenascin is concentrated in the interbarrel septae between postnatal days 2 and 9 in the mouse (Steindler et al., 1989b), at which time differentiation of interneurons and innervation by thalamocortical afferents take place (Wise and Jones, 1978). Before postnatal day 2 , tenascin is homogeneously distributed in the barrel field area, and after postnatal day 9 it becomes strongly downregulated. Tenascin demarcates the barrel field boundary represented by the septae after the arrival of the first thalamocortical axons (Jhaveri et al., 1991) and might thus not only restrict their terminal arborization to the barrel hollows, but also funnel later-arriving axons in this area by promoting axonal growth along the inner wall of the boundary. On the other hand, tenascin may limit the growth of dendrites of stellate interncurons (Lorente de Nó, 1922), whose cell bodies are located in the barrel hollows in cortical layer IV (Woolsey et al., 1975). Their neurites sprout extensively within the barrel hollows, but only occasionally cross the interbarrel septae (Woolsey et al., 1975), and display asymmetric arborization at the septal border (Loeb et al., 1987). Tenascin in the barrel septae might therefore prevent dendrites of interneurons from traversing these boundaries. Experiments perturbing the functions of tenascin at the critical developmental stages in vivo will have to be performed to resolve whether tenascin indeed plays these functional roles.

\section{References}

Akers RM, Mosher DF, Lilien JE (1981) Promotion of retinal neurite outgrowth by substratum-bound fibronectin. Dev Biol 86:179-188.

Baas PW, Deitch JS, Black MM, Banker GA (1988) Polarity orientation of microtubules in hippocampal neurons: uniformity in the axon and nonuniformity in the dendrites. Proc Natl Acad Sci USA 85:8335-8339.

Baas PW, Black MM, Banker GA (1989) Changes in microtubule polarity orientation during the development of hippocampal neurons in culture. J Cell Biol 109:3085-3094.

Banker G, Cowan WM (1977) Rat hippocampal neurons in dispersed cell culture. Brain Res 126:397-425.

Bartlett WP, Banker GA (1984) An electron microscopic study of the development of axons and dendrites by hippocampal neurons in culture. I. Cells which develop without intercellular contacts. J Neurosci 4:1944-1953.

Bartsch S, Bartsch U, Dörries U, Faissner A, Weller A, Ekblom P, Schachner M (1992) Expression of tenascin in the developing and adult cerebellar cortex. J Neurosci 12:736-749.

Bartsch U, Bartsch S, Dörries U, Schachner M (1992) Immunohistochemical localization of tenascin in the developing and lesioned adult mouse optic nerve. Eur J Neurosci 4:338-352.

Binder LI, Frankfurter A, Rebhun LI (1985) The distribution of tau in the mammalian central nervous system. J Cell Biol 101:13711378 .

Bixby JL, Jhabvala P (1990) Extracellular matrix molecules and cell adhesion molecules induce neurites through different mechanisms. J Cell Biol 111:2725-2732.

Buettner HM, Pittman RN (1991) Quantitative effects of laminin concentration on neurite outgrowth in vitro. Dev Biol 145:266-276.

Caceres A, Banker G, Steward O, Binder L, Payne M (1984) MAP2 ic Incalized to the dendrites of hippocampal neurons which develop II culture. Dev Brain Res 13:314-318.

Caceres A, Banker GA, Binder L (1986) Immunocytochemical localization of tubulin and microtubule-associated protein 2 during the development of hippocampal neurons in culture. J Neurosci 6:714722.

Calof AL, Lander AD (1991) Relationship between neuronal migration and cell-substratum adhesion: laminin and merosin promote olfactory neuronal migration but are anti-adhesive. J Cell Biol 115 : 779-794.

Chamak B, Prochiantz A (1989) Influence of extracellular matrix proteins on the expression of neuronal polarity. Development 106:483491

Chamak B, Fellous A, Glowinski J, Prochiantz A (1987) MAP2 expression and neuritic outgrowth and branching are coregulated through region-specific neuro-astroglial interactions. J Neurosci 7:3163-3170.

Chang S, Rathjen FG, Raper IA (1990) Neurite outgrowth promoting activity of $\mathrm{G} 4$ and its inhibition by monoclonal antibodies. J Neurosci Res 25:180-186.

Chun JJM, Shatz CJ (1988) A fibronectin-like molecule is present in the developing cat cerebral cortex and is correlated with subplate neurons. J Cell Biol 106:857-872.

Chuong C-M, Crossin KL, Edelman GM (1987) Sequential expression and differential function of multiple adhesion molecules during the formation of cerebellar cortical layers. J Cell Biol 104:331-342.

Crossin KL, Hoffman S, Tan S-S, Edelman GM (1989) Cytotactin and its proteoglycan ligand mark structural and functional boundaries in the somatosensory cortex of the early postnatal mouse. Dev Biol 136: 381-392.

Daniloff JK, Crossin KL, Pincon-Raymond M, Murawsky M, Rieger F, Edelman GM (1989) Expression of cytotactin in the normal and regenerating neuromuscular system. J Cell Biol 108:625-635.

Davis L, Banker G, Steward O (1987) Selective dendritic transport of RNA in hippocampal neurons in culture. Nature 330:477-479.

DeGeorge JJ, Carbonetto S (1986) Wheat germ agglutinin inhibits nerve fiber growth and concanavalin A stimulates nerve fiber initiation in cultures of dorsal root ganglia neurons. Dev Brain Res 28: $169-175$

DeGeorge JJ, Slepecky N, Carbonetto S (1985) Concanavalin A stimulates neuron-substratum adhesion and nerve fiber outgrowth in culture. Dev Biol 111:335-351.

Denis-Donini S, Glowinski J, Prochiantz A (1984) Glial heterogeneity may define the three-dimensional shape of mouse mesencephalic dopaminergic neurones. Nature 307:641-643.

Dotti CG, Banker GA, Binder LI (1987) The expression and distribution of the microtubule-associated proteins tau and microtubuleassociated protein 2 in hippocampal neurons in the rat in situ and in cell culture. Neuroscience 23:121-130.

Dotti CG, Sullivan CA, Banker G (1988) The establishment of polarity by hippocampal neurons in culture. J Neurosci 8:1454-1468. 
Dotti CG, Parton RG, Simons K (1991) Polarized sorting of glypiated proteins in hippocampal neurons. Nature 349:158-161.

Faissner A, Kruse J (1990) $\mathrm{J} 1 /$ tenascin is a repulsive substrate for central nervous system neurons. Neuron 5:627-637.

Faissner A, Kruse J, Nieke J, Schachner M (1984) Expression of neural cell adhesion molecule $\mathbf{L l}$ during development in neurological mutants and in the peripheral nervous system. Dev Brain Res 15:69-82.

Fletcher TL, Cameron P, De Camilli P, Banker G (1991) The distribution of synapsin I and synaptophysin in hippocampal neurons developing in culture. $\mathrm{J}$ Neurosci 11:1617-1626.

Fushiki S, Schachner M (1986) Immunocytological localization of the cell adhesion molecules Ll, N-CAM and the shared carbohydrate epitope L2 during development of the mouse neocortex. Dev Brain Res 289:153-167.

Gennarini G, Rougon G, Deagostini-Bazin H, Goridis C (1984) Studies on the transmembrane disposition of the neural cell adhesion molecule N-CAM. Eur J Biochem 142:57-64.

Godfraind C, Schachner M, Goffinet AM (1988) Immunohistological localization of cell adhesion molecules L1, J1, N-CAM and their common carbohydrate L2 in the embryonic cortex of normal and reeler mice. Dev Brain Res 42:99-111.

Gordon-Weeks PR, Giffin N, Weekes SSE, Barben C (1989) Transient expression of laminin immunoreactivity in the developing rat hippocampus. J Neurocytol 18:451-463.

Goslin K, Schreyer DJ, Skene JHP, Banker G (1988) Development of neuronal polarity: GAP-43 distinguishes axonal from dendritic growth cones. Nature 336:672-674.

Goslin K, Schreyer DJ, Skene JHP, Banker G (1990) Changes in the distribution of GAP-43 during the development of neuronal polarity. J Neurosci 10:588-602.

Hagg T, Muir D, Engvall E, Varon S, Manthorpe M (1989) Lamininlike antigen in rat CNS neurons: distribution and changes upon brain injury and nerve growth factor treatment. Neuron 3:721-732.

Halfter W, Chiquet-Ehrismann R, Tucker RP (1989) The effect of tenascin and embryonic basal lamina on the behavior and morphology of neural crest cells in vitro. Dev Biol 132:14-25.

Hall DE, Neugebauer KM, Reichardt LF (1987) Embryonic neural retinal cell response to extracellular matrix proteins: developmental changes and effects of cell substratum attachment antibody (CSAT). J Cell Biol 104:623-634.

Hatten ME, Furie MB, Rifkin DB (1982) Binding of developing mouse cerebellar cells to fibronectin: a possible mechanism for the formation of the external granular layer. J Neurosci 2:1195-1206.

Husmann K, Faissner A, Schachner M (1992) Tenascin promotes cerebellar granule cell migration and neurite outgrowth by different domains in the fibronectin type III repeats. J Cell Biol 116:14751486.

Hynes RO, Yamada KM (1982) Fibronectins: multifunctional modular glycoproteins. J Cell Biol 95:369-377.

Jhaveri S, Erzurumlu RS, Crossin K (1991) Barrel construction in rodent neocortex: role of thalamic afferents versus extracellular matrix molecules. Proc Natl Acad Sci USA 88:4489-4493.

Johnson MI, Higgins D, Ard MD (1989) Astrocytes induce dendritic development in cultured sympathetic neurons. Dev Brain Res 47 289-292.

Kadmon G, Kowitz A, Altevogt P, Schachner M (1990a) The neural cell adhesion molecule N-CAM enhances L1-dependent cell-cell interactions. J Cell Biol 110:193-208.

Kadmon G, Kowitz A, Altevogt P, Schachner M (1990b) Functional cooperation between the neural adhesion molecules L1 and N-CAM is carbohydrate dependent. J Cell Biol 110:209-218.

Kosik KS, Finch EA (1987) MAP2 and tau segregate into dendritic and axonal domains after the elaboration of morphologically distinct neurites: an immunocytochemical study of cultured rat cerebrum. $\mathbf{J}$ Neurosci 7:3142-3153.

Kruse J, Keilhauer G, Faissner A, Timpl R, Schachner M (1985) The $\mathrm{Jl}$ glycoprotein - a novel nervous system cell adhesion molecule of the L2/HNK-1 family. Nature 316:146-148.

Kuhn TB, Stoeckli ET, Condrau MA, Rathjen FG, Sonderegger P (1991) Neurite outgrowth on immobilized axonin-1 is mediated by a heterophilic interaction with Ll(G4). J Cell Biol 115:1113-1126.

Lafont F, Rouget M, Triller A, Prochiantz A, Rousselet A (1992) In vitro control of neuronal polarity by glycosaminoglycans. Development 114:17-29.

Lagenauer C, Lemmon V (1987) An Ll-like molecule, the 8D9 an- tigen, is a potent substrate for neurite extension. Proc Natl Acad Sci USA 84:7753-7757.

Laywell ED, Dörries U, Bartsch U, Faissner A, Schachner M, Steindler DA (1992) Enhanced expression of the developmentally regulated extracellular matrix molecule tenascin following adult brain injury. Proc Natl Acad Sci USA 89:2634-2638.

Lein PJ, Higgins D (1989) Laminin and a basement membrane extract have different effects on axonal and dendritic outgrowth from embryonic rat sympathetic neurons in vitro. Dev Biol 136:330-345.

Lein PJ, Higgins D, Tumer DC, Flier LA, Terranova VP (1991) The $\mathrm{NC1}$ domain of type IV collagen promotes axonal growth in sympathetic neurons through interaction with the $\alpha_{1} \beta_{1}$ integrin. J Cell Biol 1 13:417-428.

Lein PJ, Banker GA, Higgins, D (1992) Laminin selectively enhances axonal growth and accelerates the development of polarity by hippocampal neurons in culture. Dev Brain Res 69:191-197.

Lemmon V, Farr KL, Lagenauer C (1989) Ll-mediated axon outgrowth occurs via a homophilic binding mechanism. Neuron 2:15971603.

Lemmon V, Burden SM, Payne HR, Elmslie GJ, Hlavin ML (1992) Neurite growth on different substrates: permissive versus instructive influences and the role of adhesive strength. J Neurosci 12:818-826.

Liesi P, Silver J (1988) Is astrocyte laminin involved in axon guidance in the mammalian CNS? Dev Biol 130:774-785.

Liesi P, Dahl D, Vaheri A (1983) Laminin is produced by early rat astrocytes in primary culture. J Cell Biol 96:920-924.

Liesi P, Dahl D, Vaheri A (1984) Neurons cultured from developing rat brain attach and spread preferentially to laminin. J Neurosci Res $11: 241-251$.

Liesi P, Kirkwood T, Vaheri A (1986) Fibronectin is expressed by astrocytes cultured from embryonic and early postnatal rat brain. Exp Cell Res 163:175-185.

Lin SS, Levitan IB (1991) Concanavalin A: a tool to investigate neuronal plasticity. Trends Neurosci 14:273-277.

Lochter A, Vaughan L, Kaplony A, Prochiantz A, Schachncr M, Faissncr A (1991) $\mathrm{J} 1 /$ tenascin in substrate-bound and soluble form displays contrary effects on neurite outgrowth. J Cell Biol 113:1159-1171.

Loeb EP, Chang FLF, Greenough WT (1987) Effects of neonatal 6-hydroxydopamine treatment upon morphological organization of the posteromedial barrel subfield in mouse somatosensory cortex. Brain Res 403:113-120.

Lorente de Nó R (1922) La corteza cerebral del ratón. Trab Lab Invest Biol Univ Madr 20:41-78.

Manthorpe M, Engvall E, Ruoslahti E, Longo FM, Davis GE, Varon S (1983) Laminin promotes neuritic regeneration from cultured peripheral and central neurons. J Cell Biol 97:1882-1890.

Martini R, Schachner M, Faissner A (1990) Enhanced expression of the extracellular matrix molecule $\mathrm{J} 1$ /tenascin in the regenerating adult mouse sciatic nerve. J Neurocytol 19:601-616.

McKeon RJ, Schreiber RC, Rudge JS, Silver J (1991) Reduction of neurite outgrowth in a model of glial scarring following CNS injury is correlated with the expression of inhibitory molecules on reactive astrocytes. J Neurosci 11:3398-3411.

McLoon SC, McLoon LK, Palm SL, Furcht LT (1988) Transient expression of laminin in the optic nerve of the developing rat. $J$ Neurosci 8:1981-1990.

Mironov SL (1992) Concanavalin A: a tool to change intracellular pH. Trends Neurosci 15:13.

Osterhout DJ, Frazier WA, Higgins D (1992) Thrombospondin promotes process outgrowth in neurons from the peripheral and central nervous systems. Dev Biol 150:256-265.

Persohn E, Schachner M (1987) Immunoelectron-microscopic localization of the ncural cell adhesion molecules L1 and N-CAM during postnatal development of the mouse cerebellum. J Cell Biol 105:569576.

Persohn E, Schachner M (1990) Immunohistological localization of the neural adhesion molecules Ll and N-CAM in the developing hippocampus of the mouse. J Neurocytol 19:807-819.

Qian J, Bull MS, Levitt P (1992) Target-derived astroglia regulate axonal outgrowth in a region-specific manner. Dev Biol 149:278-294.

Rakic P (1988) Specification of cerebral cortical areas. Science 241: 170-176.

Rathjen FG, Schachner M (1984) Immunocytological and biochemical characterization of a new neuronal cell surface component (L1 antigen) which is involved in cell adhesion. EMBO J 3:1-10.

Rogers SL, Letourneau PC, Palm SL, McCarthy J, Furcht LT (1983) 
Neurite extension by peripheral and central nervous system neurons in response to substratum-bound fibronectin and laminin. Dev Biol 98:212-220.

Rousselet A, Fetler L, Chamak B, Prochiantz A (1988) Rat mesencephalic neurons in culture exhibit different morphological traits in the presence of media conditioned on mesencephalic or striatal astroglia. Dev Biol 129:495-504.

Rousselet A, Autillo-Touati A, Araud D, Prochiantz A (1990) In vitro regulation of neuronal morphogenesis and polarity by astrocyte-derived factors. Dev Biol 137:33-45.

Sokal RR, Rohlf FJ (1981) Biometry. New York: Freeman.

Steindler DA, Faissner A, Schachner M (1989a) Brain 'cordones': transient boundaries of glia and adhesion molecules that define developing functional units. Comments Dev Biol 1:29-60.

Steindler DA, Cooper NGF, Faissner A, Schachner M (1989b) Boundaries defined by adhesion molecules during development of the cerebral cortex: the $\mathrm{J} 1 /$ tenascin glycoprotein in the mouse somatosensory cortical barrel field. Dev Biol 131:243-260.

Stewart GR, Pearlman AL (1987) Fibronectin-like immunoreactivity in the developing cerebral cortex. J Neurosci 7:3325-3333.
Taylor J, Pesheva P, Schachner M (1993) The influence of janusin and tenascin on growth cone behavior in vitro. J Neurosci Res 35 : 347-362.

Tropea M, Johnson MI, Higgins D (1988) Glial cells promote dendritic development in rat sympathetic neurons in vitro. Glia 1:380-392.

Wehrle B, Chiquet M (1990) Tenascin is accumulated along developing peripheral nerves and allows neurite outgrowth in vitro. Development 110:401-415.

Wise SP, Jones EG (1978) Developmental studies of thalamocortical and commissural connections in the rat somatic sensory cortex. $J$ Comp Neurol 178:187-208.

Woolsey TA, Van Der Loos H (1970) The structural organization of layer IV in the somatosensory region (S1) of the mouse cerebral cortex: the description of a cortical field composed of discrete cytoarchitectonic units. Brain Res 17:205-242.

Woolsey TA, Dierker ML, Wann DF (1975) Mouse SmI cortex: qualitative and quantitative classification of Golgi-impregnated barrel neurons. Proc Natl Acad Sci USA 72:2165-2169.

Zar JH (1974) Biostatistical analysis. Englewood Cliffs, NJ: PrenticeHall. 